Print ISSN: 2233-4165 / Online ISSN: 2233-5382

doi:http://dx.doi.org/10.13106/ijidb.2018.vol9.no11.39.

\title{
A Success factor for Technology Commercialization for Start-ups by the Weighted-BMO Model
}

\section{$\mathrm{BMO}$ 모형을 이용한 스타트업 기술사업화 성공요인 연구*}

\author{
Kwang-Dong $\operatorname{Min}\left(\text { 민광동) }{ }^{* *} \text {, Moo-Yul Huh(허무열) }{ }^{* * *} \text {, Jeong-Hui Han(한정희) }\right)^{* * * *}$
}

Received: September 15, 2018. Revised: October 30, 2018. Accepted: October 10, 2018.

\section{Abstract}

Purpose - To success, in spite of deficient resources, a start-up company has to check various circumstances. Many researchers proposed different appraisal methods for technology commercialization. But everybody agrees Merrifield is the first one, who is a pioneer of an appraisal model of technology commercialization. After he proposed it, many researchers and field workers developed a more complicated model, which called a BMO model. In this research, considering the circumstances of start-ups that lack available resources, it proposes a new appraisal method for technology commercialization, which is named a weighted-BMO model.

Research design, data, and methology - For the new BMO-model, it studied the preceding studies. And it found that the success factors for start-ups were correlated with technology commercialization. After comparing the success factors for technology commercialization of start-ups with BMO appraisal factor, it withdraws the net BMO appraisal model: which we are calling the weighted-BMO model.

Results - This study found a few things. First, actually, the BMO appraisal factors related with the success factors of technology commercialization. Second, the weighted-BMO model, which included the entrepreneur ability factor, was more accurately estimated the success of technology-based start-ups than the BMO model. Third, it overcame the weakness of the BMO-model, which did not include quantitative factors. In addition to evaluating the feasibility of the BMO model, we also presented a strategy for the future direction. But, still, it included a few shortcomings, which we are calling the arbitrage of weighted value. Sometimes, the intentional weighted value can deliberate the different valuation.

Conclusitons - Due to this study, the weighted-BMO model included appraisal factors related with the success factors of technology commercialization and the entrepreneur ability factor, and quantitative factors. When evaluating the combined score of the existing Merrified BMO components, 35 points of the first pass criterion accounted for $29.17 \%$ of the total score, and 80 points of the merit score of the second rank criterion were $66.67 \%$ Considering that the weighted sum is taken into account, the baseline score of the weighted summing method for each component of the modified BMO model is 2.92 points, which is $29.17 \%$ of the weighted sum total of 10 points. The evaluation score was 6.67 points, $66.67 \%$ of the weighted total score of 10 points.

Keywords: BMO Model, The Technology Commercialization of Start-ups.

JEL Classification: L1, M0, M1.

\footnotetext{
* This Paper was Modified and Developed from the Master Thesis of the Co-Author.

** First Author, Doctoral student, Department of Global Plicy, Gongju National University, Korea. Tel: +82-41-961-5821, E-mail: kdantony@naver.com

*** Corresponding Author, Professor, Department of Global Plicy, Gongju National University, Korea.

Tel: +82-41-850-0811, E-mail: hmyag@kongju.ac.kr
}

1. 서론

1.1. 연구의 배경 및 목적

최근 불경기 및 높은 실업률로 인해 정부에서는 이의 해결 방안 중 하나로 창업을 장려하고 있다. 특히 기술창업의 경우

\footnotetext{
**** Third Author, Doctoral Student, Department of Global Plicy, Gongju National University, Korea. Tel: +82-42-348-1004, E-mail: 310607@hanmail.net
} 
출연연구원 및 공기업 등에서도 기술상용화의 한 방편으로 장 려되고 있다. 2011년 산업연구원에서 366개 기업을 대상으로 한 설문조사에 의하면, 성공사례의 $54.3 \%$ 가 성장기 기술을 사 업화 대상으로 하고 있는 것으로 나타났다. 이러한 성장기 기 술은 보완기술 즉, 기술사업화의 대상이 되는 기술과 결함되어 해당 기술의 가치를 높일 수 있는 기술이 존재하는 경우가 많 다. 또한 해당 기술이 적용될 수 있는 시장이 충분히 성숙되어 있어 이를 대체할 대체기술이 존재하는 경우도 많다. 이러한 기술사업화 대상이 되는 기술이 가진 특징으로 인해 우리나라 의 기술사업화는 생존률이 높은 시제품 제작 및 양산 직전 단 계에서 시작되는 경향이 강하다.

하지만 기술창업기업이 사업화의 과정 중에 겪게 되는 문제 는 비단 기술과 관련된 부분 만이 아닌, 재무, 마케팅, 인력 등등 여러 영역에 걸쳐 발생한다. 따라서 자원과 인프라가 부 족한 창업기업의 특성 상 이러한 사업화 과정 중에 발생할 수 있는 문제들을 사전에 검토할 수 있는, 사업 타당성 검토 작업 은 업력이 있는 기업에 비해 더욱 중요하다. 하지만 이러한 기 술기반 창업기업들의 기술사업화 성공가능성을 평가하는 적절 한 수단이 부족하다고 판단되어, 본 논문은 창업기업의 성공적 인 기술사업화 방안 수립과 실행을 사전적으로 가늠해볼 수 있는 방법론을 제시하고자 한다. 특히 Merrifield의 $\mathrm{BMO}$ 모델을 기반으로 하여, 창업기업의 기술사업화를 위한 $\mathrm{BMO}$ 모델 구성 요소를 살펴보았다.

따라서 본 논문은 다음의 연구들을 수행하였다. 첫째, 이론 적인 검토를 통해 창업기업의 성공요인과 기술사업화 영향요 인 간의 상관관계를 고찰하였다. 둘째, 위 상관관계를 통해, 창업기업에 적용할 수 있는 기술사업화 성공요인을 제시하였 다. 셋째, 이러한 창업기업의 기술사업화 성공요인과 첫 번째 로 고찰했던 $\mathrm{BMO}$ 구성요소 간의 상관관계를 통해, 창업기업의 기술사업화에 필요한 $\mathrm{BMO}$ 구성요소를 기존 Merrifield $\mathrm{BMO}$ 구 성요소에서 변형하고, 구성요소별 가중치를 부여하여 창업기업 의 기술사업화에 적합한 모델로 수정하였다.

\section{2. 선행연구 고찰}

\section{1. 기술사업화에 관한 이론적 고찰}

\subsection{1. 기술사업화의 정의}

기술의 이전 및 사업화 촉진에 관한 법률(이하 '기술이전촉 진법')에서는 '사업화라 함은 개발된 기술을 이용하여 제품의 개발, 생산 및 판매를 수행하거나 그 과정의 관련기술의 향상 에 적용하는 것을 말한다'고 규정한다. 하지만 이렇게 개별 법 령 조항에 적시된 내용만으로는 기술사업화에 대한 유형을 포 괄하지 못하고 있어, 학자별로 기술사업화에 대한 정의를 다르 게 내리고 있다.

먼저 '기술'의 사전적 정의를 살펴보면, 국립국어원 표준국 어대사전에 의하면 '과학이론을 실제로 적용하여 자연의 사현, 물을 인간 생활에 유용하도록 가공하는 수단' 또는 '사물을 잘 다룰 수 있는 방법이나 능력'이라고 정의한다. Webster사전에 서는 기술을 '문제를 해결하거나 유용한 어떤 것을 발명하기 위해 산업이나 공학분야의 과학을 사용하는 것'으로 정의하고 있으며, 세계지적재산원(WIPO)에서는 기술을 '특정 분야 지식 의 실제적 응용과정, 절차, 제조 또는 공업, 농업, 상업 분야에
서의 서비스 제공을 위한 체계화된 지식'으로 정의한다. 그리 고 기술이전촉진법에서 기술의 정의는 '특허법 등 관련 법률에 따라 등록 또는 출원된 특허, 실용신안, 디자인, 반도체 집적 회로의 배치설계 및 소프트웨어 등 지식재산, 기술이 집적되 자본재, 기술에 대한 정보, 기타 이에 준하여 대통령령이 정하 는 것'이라 되어 있다. 그리고 글로벌 시장에서 베트남기업들 이 기술경영과정에서 선진국에 비해 부족한 점이 무엇인가를 고찰하였던 Tuan, Thanh, and Loc(2018) 연구에서 언급되었 던 베트남 과학사전에서는 이 기술을 여섯 가지 개념 즉 과학, 기술적 수단, 제품제조세트, 생산을 위한 부품 및 서비스, 생 산관점에서의 산출물, 최첨단기술 및 조직구조 등으로 보는 관 점으로 보기도 하였다.

위와 같이 기술에 대한 사전적·법률적 정의에서 기술은 사 물의 제조·가공기법을 의미하는 개념을 포함한, 서비스·지식재 산-정보 등을 포괄하는 모든 형태의 지적 노하우를 포함하고 있음을 알 수 있다.

다음으로 '사업화'의 정의를 살펴보면, 먼저 '사업'의 사전적 정의는 '어떤 일을 일정한 목적과 계획을 가지고 짜임새있게 지속적으로 경영함 또는 그 일'이다. 따라서 '사업화'란 '어떤 일을 일정한 목적과 계획을 가지고 짜임새 있게 지속적으로 경영하게 하는 과정' 정도로 정의될 수 있겠다. 이에 Lee (2008)은 사용자 및 사용용도에 따라 사업화와 함께 사용되는 개념으로 상용화, 실용화, 기업화 등의 내용을 다맀다. 여기서 상용화를 광의, 중범위, 협의의 의미로 분류하여 정의내렸는데 이의 내용은 다음과 같다.

먼저 광의의 상용화는 연구개발계획수립, 아이디어 창안을 통해 연구개발 및 기술개발, 개발된 기술을 활용 및 개량하여 시장에서 제품수명주기를 연장 또는 새로운 수명주기 창출과 관련된 일련의 제 활동을 의미한다. 그리고 중범위의 상용화는 연구개발된 기술을 이전하여 시제품을 제작하고 엔지니어링 기술과 결합하는 단계에서의 활동을 의미한다. 또한 협의의 상 용화는 자체 기술개발 또는 기술이전을 통하여 획득한 기술을 제조공정활동에 투입함으로 제품제작, 출시 및 판로개척에 이 르는 과정을 의미하며 이를 사업화라고도 한다.

그리고 실용화는 과학기술부 및 관련기관에서 주로 사용하 는 용어로 기술이나 제품의 시장도입여부와 별개로 실제 사용 여부를 강조하는 경우로, 사업화기획 초기단계부터, 시제품 제 작 및 시험판매 등에 이르기까지 이와 관련된 행동을 의미한 다. 마지막으로 기업화는 협의의 상용화와 대동소이한 개념으 로 산업관련 민간기관에서 주로 사용되는데, 기술개발 과정 이 후 제품이 시장에 도입되어 영리를 창출하는 일련의 장기전략 관점에서 기술채택, 생산, 마케팅활동 및 시장개척활동이 이루 어지는 경우를 의미한다.

위에서 언급한 상용화, 실용화, 기업화 개념은 모두 '기술개 발-기술활용-관련기술 확산'이라는 측면에서 유사하여, 연구자의 연구목적이나 성향, 환경조건 등을 감안하여 용어를 선택할 수 있으며, 이러한 개념들의 영문명칭은 모두 'commercialization' 으로 사용되고 있다.

이제까지 기술과 사업화와 관련된 개념을 정리해봤는데, 이 제 이 두 개념이 합쳐진 '기술사업화'에 대한 용어를 현행 개 별법령에서는 다음과 같이 정의내리고 있다. 먼저 기술의이전 및사업화촉진에관한법률 제2조에서는 기술을 이용하여 제품을 개발-생산 또는 판매하거나 그 과정의 관련기술을 향상시키는 것을 말하며, 정보통신진흥및융햡활성화등에관한특별법 제2조 제19조에서는 정보통신 관련연구 또는 기술을 활용하여 개발. 
제조·제작된 기술, 제품 및 서비스를 영이를 목적으로 판매·유 통·제공하는 등 경영활동으로 연결시키거나 경영활동을 하는 단체 또는 조직을 형성하는 일련의 과정을 말한다.

이렇게 기술사업화에 대한 정의는 여러 영역에서 다양하게 내려지고 있으나, 앞서 서술한 기술, 사업화, 기술사업화에 대 한 개념을 요약해보면 결국 기술사업화는 '기술을 이용하여 제 품·서비스를 개발·생산·판매하거나 관련기술을 향상시키는 과 정'으로 정의내릴 수 있다.

\subsection{2. 기술사업화의 유형}

기술사업화 개념이 다양한 만큼 유형 역시 다양하다. 공공/ 민간 영역에 따라 달라지며, 사업형태 즉, 창업/기술이전/분사/ 연구개발용역 등에 따라서도 달라지고, 사업주체 즉 연구원/교 수/기업 등에 따라서도 달라진다. 기술사업화 유형을 영역별로 구분하고 이를 사업주체에 다라 세분화하면 공공기술 이전 사 업화, 공공기술 개발자 창업, 자체기술 사업화, 이전기술 사업 화 등으로 정리해볼 수 있다.

먼저 공공기술 이전 사업화는 정부 기술개발 자금의 투입으 로 개발된 기술을 민간기업에 이전하여 사업화하는 것을 의미 한다. 그리고 공공기술 개발자 창업은 대학 및 공공연구관이 주관이 되어 개발한 기술을 기술개발에 참여한 교수, 연구원 등으로 하여금 창업 및 사업화하도록 하는 것을 의미한다. 그 리고 자체기술사업화는 민간기업이 자체 개발하였거나 공동으 로 개발한 기술을 직접 제품화하여 판매하는 방안을 의미하며, 이전기술 사업화는 기술의 판매희망자와 구매자가 연결되어 민간부분에서 해당 기술의 거래가 이루어지고 이를 사업화하 는 방안을 의미한다.

또 다른 기술사업화의 유형으로 양도, 실시권허락, 기술지 도, 공공연구, 기술창업, 합작투자 또는 기술지주회사 설립 등 의 기술출자방식, 인수합병 등이 있다. 먼저 1) 양도는 공공연 구기관, 민간기업 등 기술보유주체가 기술도입자(민간기업)에 게 기술의 소유권을 이전하는 경우를 의미한다. 그리고 2) 실 시권 허락은 기술보유자가 기술도입자에게 기술의 실시권 (license)를 허락하는 경우다. 3) 기술지도는 위의 양도 혹은 실시권 허락과 병행하여 이루어지는데 기술보유자가 기술도입 자에게 기술의 적용을 위한 교육·훈련을 제공하는 경우이다. 4) 공동연구는 공공연구기관 등의 기술보유자가 기술도입자에 게로 기술이전을 목적으로 수행하는 공동연구를 의미한다. 5) 기술창업은 기술보유자의 연구자 등 소속 직원이 직무잘명 등 을 이전 받아 창업 혹은 창업에 참여하는 경우릴 의미한다. 6) 합작투자는 기술보유자와 기술도입자가 합작하여 제 3 의 기업 을 설립하고 사업화를 추진하는 경우를 의미하는데 여기서 기 술보유자가 공공연구기관인 경우는 주로 보유기술을 현물출자 하여 참여하게 된다. 7) 기술지주회사는 공공연구기관 등의 기 술보유자가 기술지주회사를 설립하고, 보유기술을 자본금 형식 으로 출자하여 기술사업화를 목적으로 하는 자회사를 운영하 는 경우를 의미한다. 8) 인수합병은 주로 민간기업 등 기술도 입자가 사업화 추진을 위해, 필요한 기술과 경영 인프라를 보 유한 기술보유자를 인수·합병하는 경우를 의미한다(KIET, 2008).

\subsection{3. 기술사업화 성과에 관한 선행 연구}

우리나가 국가연구개발사업의 경우, 과제 수행 시 성공판정 을 받거나, 기술 실시계약을 체결하는 경우 기술사업화가 성공
한 것으로 간주하기도 한다. 하지만 기술사업화의 정의에 따라 성공 기준이 달라질 수 있다. 다음은 기술사업화 성과에 관한 학자들의 연구이다.

먼저 Jolly(1997)는 기술가치를 증대시키는 일련의 단계적 활동으로 기술사업화를 정의하여, 초기 사업화 단계부터 제품 시장 진입과 개선단계에 이르는 전체 프로세스를 다룬다고 언 급하고 있다. Jolly(1997)는 이렇게 '착상, 보육, 시연, 촉진, 지 속'으로 이어지는 일련의 혁신 및 연구개발 과정을 중심으로 , 아이디어 제안, R\&D, 시제품 제작, 시장진입, 대량생산 및 지 속적 성장으로 프로세스 전반을 수행하는 것‘을 기술사업화의 성공으로 여겼다.

그리고 Kummar(2002)는 '시장의 요구를 만족시키기 위해 장비나 시설을 이용하여 기술의 가치를 올려 제품을 최적화시 키는 것'을 기술사업화로 정의내리고, 신기술 사업화에 대한 실증연구를 기업, 재무제도, 기술제도, 정책입안자 네 가지 주 요관점에서 수행하였다.

또한 $\mathrm{Yam}(2004)$ 은 기술사업화 성공을 혁신성과·판매성과제품성과 부분으로 분류하여 정리하였다. Yam (2004)은 중국 에 소재한 213 개 기업을 대상으로 기술사업화 성과를 기술혁 신역량(학습·R\&D·자원할당·제조·마케팅·조직화·전략실행)과의 관계로 고찰한 결과, R\&D 및 자원할당역량이 기술사업화 성 과에 가장 중요한 역할을 하는 것으로 나타났다. 특히 R\&D역 량은 중간규모 기업의 혁신성과와 제품성과에 중요한 영향을 미치는 것으로 확인되었다. 그리고 자원할당 역량은 소기업의 혁신성과와 제품성과에, 마케팅 역량은 소기업의 제품성과에 중요한 영향을 미치는 것으로 파악되었다.

$\operatorname{Lin}(2006)$ 은 미국의 기술기반기업 258 개의 재무 데이터와 특허를 이용한 연구를 수행한 결과, 사업화지향성이 재무적인 관점에서 사업화 성과와 가장 관련이 높으며, R\&D집약도는 이에 보완적인 효과를 가지는 것을 밝혔다.

물론 사업화 실패에 대한 연구도 이루어졌는데, Lee(2014) 은 중진공 청년전용자금 활용기업을 사례로 창업기업의 창업 초기 생존전략 연구에서 Bin and Park(2002)의 연구를 인용하 여, 창업실패 요인으로 경영관리 미숙, 시장확보 실패, 급변하 는 사업환경에 능동적으로 대처 미흡 등을 실패요인으로 들었 다.

그동안 서술한 연구들을 종합해보면 기술사업화 성공은 결 국 '고객의 심각한 문제해결을 해결해줄 수 있는 기술 해법을 제품/서비스에 구현하고, 시장에 최적화시켜, 수익창출 단계에 도달하는 것'으로 정리할 수 있다.

\subsection{4. 기술사업화 영향요인에 관한 선행연구}

미국은 공공부문에서 개발한 기술의 사업화 성공에 미치는 영향요인에 대한 연구가 1970년대 이후부터 꾸준히 이루어져 오고 있다. 이들 연구에 따르면, 정부연구소 및 대학에서의 기 술사업화 및 확산에 영향을 미치는 요인으로 기술자체의 속성, 기술사업화 조직 전략, 기술개발 주체가 처한 조직의 내부 및 외부 환경 등을 들고 있다(KIET, 2011). 이렇듯 기술사업화 영 향요인에 관한 연구는 다양한 관점에서 이루어지고 있는데, 다 음은 기술사업화 영향요인에 대한 학자들의 연구이다.

$\mathrm{KIET}(2011)$ 은 문헌연구를 통하여, 기술사업화 영향요인을 기술개발자, 기술적속성, 기술수용자, 외부환경 등 네 가지 범 주로 제시하였다. 해당범주의 관련변수를 구체적으로 살펴보면 다음과 같다. 먼저 기술개발자 요인의 범주로는 사업화 경험 
(McEachron, 1978), 기술사업화에 대한 인식수준(Baer et al., 1976), 현장기술감각(Radosevich \& Smith, 1997), 산·학·연 협 력 및 연계(Song \& Ryu, 2002) 등이 있다. 그리고 기술적속성 요인의 범주에 기술 성숙도(Brown et al., 1991), 기술 신뢰성 (Rothwell, 1992), 기존 기술과의 연계성(Cooper, 2001) 등을 들고 있다.

앞서 설명한 첫 번째, 두 번째 범주의 영향요인이 기술 내 적 요인인 것과 달리, 세 번째 요인인 기술수용자 요인과 네 번째 요인인 외부환경 요인은 기술 외적 요인에 해당된다. 먼 저 기술수용자 요인으로는 경영자의 의지, 신기술에 대한 위험 부담능력, 사업화 전문인력, 사업화 자금조달능력 등을 든다 (Rothwell, 1992; Ettlie, 1982; Lester, 1998). 그리고 외부환경 요인으로는 기술사업화 네트워크(Song \& Ryu, 2002), 지식재 산권 보호(Daeho Song, 2006), 정부정책(Sungil Go, 2004), 제 품시장의 특성(Cooper, 1979) 등을 든다.

지금까지 기술사업화 영향요인을 다룬 국내 연구 문헌에 대 해 살펴보았다. 다음은 해당 요인에 대한 해외 연구 문헌에 대 해 살펴보겠다.

Baer(1976)는 기술사업화 영향요인으로 기술개발자의 사업 화 의지, 기술사업화에 대한 인식 수준, 잠재적 시장과 제조업 자를 포함한 산업시스템을 주요요인으로 들었고, Ettlie(1992) 는 기존 기술 및 사업화 대상 기술과의 관련성, 정부의 정책 및 정책적 대안, 조직의 상황적요인(최고경영층의 의지, 신기 술에 대한 위험부담능력, 기술사업화 자금조달 역량, 기술사업 화 관련 전문적 역량)을 그 주요요인으로 든다. 그리고 Jolly (1997)는 사업관심도와 사업화 가능성의 관점에서 기술사업화 영향요인을 설명하는데, 사업관심도 측면에서는 시장매력도와 기존기술 및 인프라를, 사업화 가능성 측면에서는 상용화 용이 성, 적용특이성, 발생문제의 범위를 그 영향요인으로 들고 있다.

또한 Lester(1988)는 최고경영자 관심도(경영자 비전, 조직 문화), 조직(운영)특성(신제품 개발조직, 전략/직능 가이드, 개 발과정의이해), 신제품 개념도출(전문경험, 기술 어플리케이션), 벤처구성(개별적 숙련도, 역할기대), 프로젝트 관리(전술개발, 측정수단 개발, 외부요인분석, 관리적 의사소통, 재평가작업, 외부전문가) 측면에서 영향요인을 설명하고 있다.

마지막으로 Rothwell(1977)은 연구결과, 연구전략, 연구혁신 관점에서 영향요인을 설명하고 있다. 여기서 연구결과란 내/외 부 의사소통, 기업수준의 혁신관리, 계획/프로젝트 관리, 품질/ 생산효율성, 시장지향성, 핵심인력 유무, 기술서비스 수준, 고 객관리 수준 등을 그 내용으로 하며, 연구전략은 CEO 참여 및 지원, 중장기 기업전략, 주요 프로젝트 관리, 기업의 유연 성/적응성, 위험의 인식/수용, 혁신관리/조직문화 등을 그 내용 으로, 연구혁신은 기업통합/네트워킹, 기술적 축적, 통합생산/ 제품전략, 조직의 유연성, 제품품질/성과, 환경적응력, 시장적 응력 등을 그 내용으로 한다.

또한 최근 들어, 그린벤처라고 일컬어지는 비영리법인 스타 트업의 아이템도 기술사업화의 결과물로 이루어지는 경우가 많은데, 그리하여 Majid and Yaqun(2016)은 해당연구에서 비 영리 스타트업의 기술사업화에 있어서 이의 성공을 위한 내적 요인으로 Entrepreneur의 개념과 유사한 sustainopreneurs 개 념을 제시하기도 하였다. 그리고 이의 개별적인 사례로써 Syi and Su(2014)는 하이테크 제품들의 구매에 영향을 주는 요인 에 대한 연구를 기존 개발자 관점에서의 요인들이 아닌, 구매 자 관점에서 진행하여 사회적 이미지, 매력, 문제해결을 위한 편의성 등을 영향요인으로 언급한 바 있다.

\subsection{5. 기술사업화 성공요인}

지금까지 언급한 기술사업화 영향요인과 관련된 국내외 문 헌연구, KIET산업연구원의 기술사업화 영향요인 범주를 참고하 여 기술사업화 성공요인을 정리하면 다음 <Table $1>$ 과 같다.

Table 1: The success factors of technology commercialization

\begin{tabular}{|c|c|c|}
\hline $\begin{array}{l}\text { Success } \\
\text { Factors }\end{array}$ & Related Variables & Researcher \\
\hline $\begin{array}{l}\text { Technology } \\
\text { provider }\end{array}$ & $\begin{array}{l}\text { Commercialization experience } \\
\text { Level of awareness of } \\
\text { technology commercialization } \\
\text { On-site technical sense } \\
\text { Industry-academia-research } \\
\text { cooperation and linkage }\end{array}$ & $\begin{array}{c}\text { McEachron(1978) } \\
\text { Baer et al.(1976) } \\
\text { Radosevich and } \\
\text { Smith(1997) } \\
\text { Song \& Ryu } \\
\text { (2002) }\end{array}$ \\
\hline $\begin{array}{l}\text { Technical } \\
\text { Properties }\end{array}$ & $\begin{array}{l}\text { Technology maturity } \\
\text { Reliability of technology } \\
\text { Connection with existing } \\
\text { technology (business) }\end{array}$ & $\begin{array}{c}\text { Brown et al.(1991) } \\
\text { Rothwell(1992) } \\
\text { Cooper(2001) }\end{array}$ \\
\hline expropriator & $\begin{array}{l}\text { Management's will } \\
\text { Ability to risk new technology } \\
\text { Professionalization staff } \\
\text { Commercialization funding } \\
\text { capability }\end{array}$ & $\begin{array}{l}\text { Rothwell(1992) } \\
\text { Ettlie(1982) } \\
\text { Lester(1998) }\end{array}$ \\
\hline $\begin{array}{c}\text { External } \\
\text { environment }\end{array}$ & $\begin{array}{l}\text { Technology Commercialization } \\
\text { Network } \\
\text { Intellectual Property Protection } \\
\text { Government policy } \\
\text { Characteristics of the product } \\
\text { market }\end{array}$ & $\begin{array}{l}\text { Song \& Ryu } \\
(2002) \\
\text { Song(2006) } \\
\text { Go(2004) } \\
\text { Cooper(1979) }\end{array}$ \\
\hline
\end{tabular}

\section{2. $\mathrm{BMO}$ 모델 선행연구}

\subsection{1. $\mathrm{BMO}$ 모델 개요}

$\mathrm{BMO}$ 모델은 벤처기업의 사업타당성을 검증하는 모델로 본 래는 연구개발 테마 선정을 위해 개발되었다. 미국 펜실베니아 대학 와튼스쿨 교수로 재직하던 Merrifield가 제안한 것을 일본 의 오오에(Ohe) 교수가 신규사업 및 아이템 선정을 위해 적합 도 판정기법으로 수정한 방법론이다. 해당 모델은 미국 상무성 및 대기업, 비즈니스스쿨 등에서 활용되어왔는데 고성장 가능 성을 지닌 벤처를 찾아내는 기준을 계량적으로 정리 분석하여, 그 예측 정확도가 실제 연구를 통해 검증되어 Eun(2007)에 의 하면 이 방법으로 판정된 아이템의 성공률이 $83 \%$ 라고 언급되 어 있다.

기술마케팅 전략 유형 조절변수에 대해 연구한 $\operatorname{Han}(2016)$ 의 연구에 의하면 산업 성장률, 경쟁강도, 진입장벽의 산업구 조가 기술창업 성과에 중요한 영향을 미친다는 결과를 보여주 는데, 이는 특히 $\mathrm{BMO}$ 모델에서 다루는 1단계 평가기준이 산업 구조를 분석하는 것과 관련된 항목으로, 사업화 성공 타당성을 평가할 때 산업구조를 검토하는 것이 매우 중요하다는 것을 나타낸다. 또한 이와 유사한 맥락에서 Cinar, Isin, and Hushmat(2016)의 연구에도 사업 타당성 검증의 일환으로 리 
스크 매니지먼트 관점에서 시장에서 긍정적 인식을 환기시키 거나, 정책적으로 회사에 재정지원을 하는 것 등과 같은 정책 도구의 중요성을 언급하고 있다.

이 모델로 사업타당성을 평가할 때, 총점 120점 만점으로, 매력도 60 점, 자사 적합도 60 점으로 구분하고 있다. 매력도는 외부요인으로 시장수요측면, 기술 및 정책적 측면 등을 고려하 고, 내부적 요인은 해당 아이템의 사업화를 위한 자사 즉, 벤 처기업의 역량을 체크하게 된다. 아이템 선정을 위한 각각의 사업매력도, 자사 역량 적합도의 세부적인 평가항목은 <Table $2>$ 와 같다. 여기서 외부요인에 의한 사업매력도는 최소한 35 점 이상이 되어야 하고, 자사 역량 적합도는 최소한 20점 이 상이 되어야 한다. 그리고 사업매력도와 자사 역량 적합도의 합이 80점 이상이 되면 유망 아이템으로 여겨진다.

$\mathrm{BMO}$ 평가는 1단계에서 2단계로 순차적이고 누적식으로 평 가하며, 각 단계는 60 점 총점으로 따라서 총점은 120 점 만점 이다. 1단계는 사업매력도 평가다. 1단계에는 6 개 항목 60 점 만점으로 되어 있으며, 평가결과 60점 만점에 35점 이상이면 2단계로 진행되고, 35점 미만이면 사업성이 미흡한 것으로 보 완 혹은 포기해야 한다.

Table 2: Evaluation items and points by BMO

\begin{tabular}{|c|c|c|c|}
\hline \multicolumn{4}{|c|}{ BMO Analysis } \\
\hline $\begin{array}{c}\text { Business } \\
\text { Attractiveness(60) }\end{array}$ & score & Busines Fit(60) & score \\
\hline $\begin{array}{c}\text { Sales } \\
\text { /profit potential }\end{array}$ & 10 & Capital requirements & 10 \\
\hline Growth rate \% year & 10 & Marketing capabilities & 10 \\
\hline Competitive situation & 10 & $\begin{array}{c}\text { Manufacturing } \\
\text { capabilities }\end{array}$ & 10 \\
\hline Risk distribution & 10 & Technology base & 10 \\
\hline $\begin{array}{c}\text { Opportunity to restructure } \\
\text { an entire industry }\end{array}$ & 10 & $\begin{array}{c}\text { Raw-materials } \\
\text { availability }\end{array}$ & 10 \\
\hline $\begin{array}{c}\text { Special political and } \\
\text { social factors }\end{array}$ & 10 & Skills availability & 10 \\
\hline
\end{tabular}

2단계는 자사의 역량(창업자)과의 적합도를 평가한다. 2단계 역시 6 개 항목 총합이 60점 만점으로 구성되어 있으며, 평가 결과 매력도와 적합도의 점수가 80 점 이상인 경우에는 3 단계 평가를 수행하며, 80 점 미만인 경우에는 사업을 보류하거나 재검토 하는 것이 요구된다.

3 단계는 사업화 성공확률에 대비시키는 단계이다. 1단계보 다 2단계 평가 기준점이 높은 것은 사업성공화 확률 곡선과 밀접한 관련이 있다. 여기서 $\mathrm{BMO}$ 모델은 성장가능성이 높은 이상적인 비즈니스 모델인지를 평가하기 위해 크게 네 가지 기준을 제시한다.

1) 다양한 세분시장이 존재하고, 그중 어떤 것을 선택해도 규모가 크며, 5년 후에는 1조원 이상이 되는 사업

2) 향후 5 년 간, 특정 기간동안 데이터의 연평균성장률을 의미하는 CAGR(Compound Annual Growth Rate)이 매 년 2배로 성장하고, 모든 지적재산권을 소유하고 있어서 경쟁상대는 아무도 없는 사업

3) 다양한 세분시장에 응용할 수 있고, 새로운 업계가 구축 될 가능성도 있으며, 세제상의 우대책도 있는 사업
4) 1 천억 원 정도의 자금이 필요하지만 자사에서 조달 가능 하고, 현재 보유하고 있는 판매망/제조설비/기술력으로 모든 것을 조달할 수 있으며, 원자재 역시 특별할 것이 없는 사업

하지만 이와 같이 이상적인 신규사업은 현실적으로는 거의 존재하지 않는다. 따라서 $\mathrm{BMO}$ 모델은 현실의 신규사업이 이상 적인 신규 사업에 비해 얼마나 다른가를 척도로 평가하는 방 법이라 할 수 있다.

아래 <Figure 1>은 BMO평가에 의한 사업성(매력도+적합성) 평가점수에 따른 성공확률을 나타낸 곡선으로, 사업성 평가점 수가 80점 이상인 경우에 사업화를 추진하는 것이 바람직하다 는 것을 나타낸다. 그리고 한편 <Figure 2>는 $\mathrm{BMO}$ 평가결과 에 대한 사업화 추진결정 조건을 나타낸 도식으로 해당사업의 매력도가 35점 이상인 경우 사업화 추진을 검토하되 사업성 (매력도+적합성)이 80점 이상인 경우 사업화 추진을 결정한다 는 의미를 나타낸다.

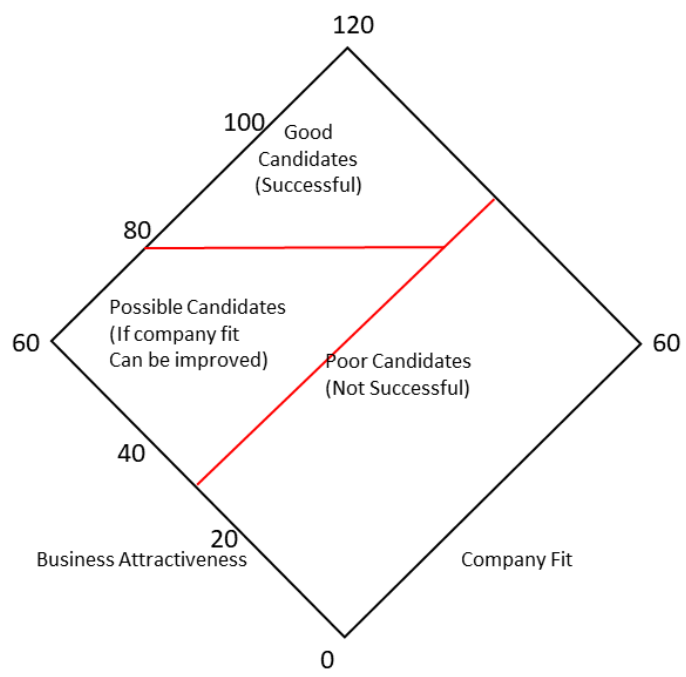

Figure 1: The probability of successful commercialization

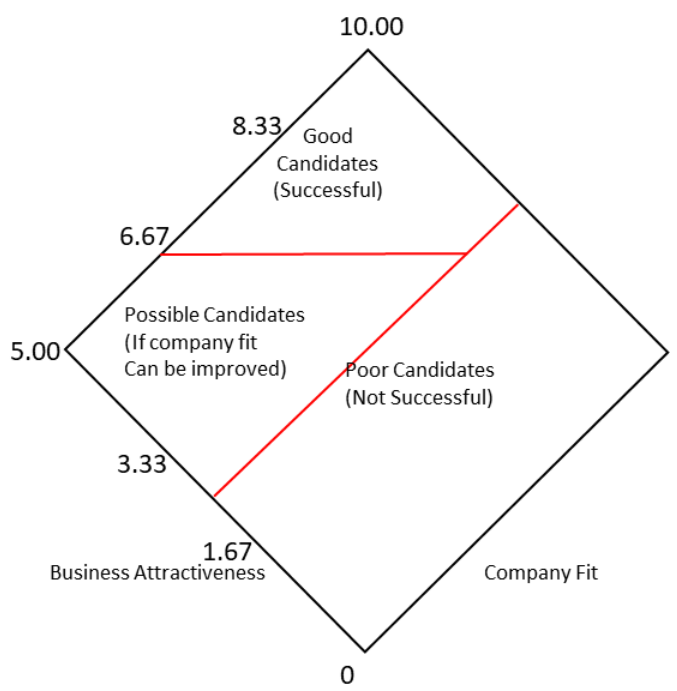

Figure 2: The decision to implement commercialization 


\subsection{2. $\mathrm{BMO}$ 모델 평가항목 구성요소}

$\mathrm{BMO}$ 모델은 사업매력도(Business Attractiveness Factors)평 가와 사업 적합도(Business Fit Factors)평가의 2부분으로 이루 어져 있다. 우선 사업 매력도 평가는 1단계로서 탑다운 관점 의 평가항목들로 이루어져 있는데, 매출규모, 시장성장성, 경 쟁력, 위험 분산도, 업게 재구축 가능성, 특별한 사회적 상황 에 관련된 요소들을 평가한다. 자사적합도 평가는 평가의 제 2 단 계로서 바텀업 관점에서 사업추진 회사의 자본력, 마케팅력, 제 조력, 기술력, 원자재 조달력, 경영지원 등의 요소를 평가한다.

\subsubsection{1. 사업매력도}

먼저 사업매력도는 사업이 속해있는 산업의 환경과 속성을 고려하여 이 사업이 얼마나 매력적인 사업인가를 다음의 6 가 지 기준으로 평가한다.

\section{(1) 시장규모(판매·이익 가능성)}

투자수익률(ROI)과 5년 후 시장 규모를 고려하여 수익 잠재 성을 평가한다. 시장규모는 관련기술의 신규성, 세분시장의 양 상과 성장률, 경쟁업체, 기술현황, 신규 사업 기회 등을 조사 하여 평가 시 고려한다.

Table 3: Estimated market scale \& score

\begin{tabular}{|c|c|c|c|c|c|}
\hline $\begin{array}{c}\text { Market } \\
\text { size }\end{array}$ & $\begin{array}{c}\text { more than } \\
\mathbf{1} \text { trillion } \\
\text { won }\end{array}$ & $\begin{array}{c}\text { less than } \\
\mathbf{1} \text { trillion } \\
\text { won }\end{array}$ & $\begin{array}{c}\text { less than } \\
\mathbf{5 0 0} \text { billon } \\
\text { won }\end{array}$ & $\begin{array}{c}\text { less than } \\
\mathbf{5 0 0} \text { billion } \\
\text { won }\end{array}$ & $\begin{array}{c}\text { less than } \\
\mathbf{1 0} \text { billion } \\
\text { won }\end{array}$ \\
\hline Score & 5 & 4 & 3 & 2 & 1 \\
\hline
\end{tabular}

Table 4: ROI \& score

\begin{tabular}{|c|c|c|c|c|c|c|}
\hline ROI & $\begin{array}{c}\text { more than } \\
\mathbf{2 0} \%\end{array}$ & $\begin{array}{c}\text { less than } \\
\mathbf{2 0} \%\end{array}$ & $\begin{array}{c}\text { less than } \\
\mathbf{1 5 \%}\end{array}$ & $\begin{array}{c}\text { less than } \\
\mathbf{1 0} \%\end{array}$ & $\begin{array}{c}\text { less than } \\
\mathbf{5} \%\end{array}$ & $\begin{array}{c}\text { less than } \\
\mathbf{1} \%\end{array}$ \\
\hline score & 5 & 4 & 3 & 2 & 1 & 0 \\
\hline
\end{tabular}

투자가 필요 없을 경우에는 5 점을 부여하며, 해당 사업에 대한 일반적인 $\mathrm{ROI}$ 가 있을 경우에는 이 값을 사용한다.

(2) 성장성(시장의 성장 가능성)

시장진입장벽, 접근 가능성, 기술진부화 속도, 덤핑 영향 등 을 고려하여 시장의 성장 가능성을 평가한다. 연평균 $20 \%$ 이 상의 성장률을 보일 가능성이 있을 때 성장 잠재력이 높은 것 으로 여긴다.

Table 5: CAGR score

\begin{tabular}{|c|c|c|c|}
\hline CAGR & more than $\mathbf{2 0} \%$ & more than $\mathbf{1 4} \%$ & more than $\mathbf{1 0} \%$ \\
\hline score & 10 & 7 & 5 \\
\hline
\end{tabular}

\section{(3) 경쟁력(경쟁상황 분석)}

여기서는 상품 서비스의 수명, 특허 및 상표 방어가능성, 선 발기업과 예상 진입 기업의 대응력 강도 여부를 평가한다. 점 수 배점은 다음과 같다. 먼저, 선발기업과 참여예상 기업의 대 응력 강도에 따라 0점에서 4점을 부여하는데, 선발기업이 시 장을 석권하고 있을 경우 0점, 선발기업도 없고 예상 진입자 도 없을 경우 4점이다. 즉, 선발기업과 예상 진입자의 대응력
강도가 낮을수록 점수가 높다.

그리고 제품/서비스의 수명에 따라 1점에서 3점을 부여한다. 제품, 서비스의 수명이 3년 이하는 1점, 3년 이상은 2점, 5년 이상은 3점이다. 또한 특허나 상표에 의한 방어가능성 점수를 0점에서 3점을 부여한다. 노하우나 지적재산권 등이 없는 사업 인 경우 0점, 강력한 특허 또는 상표를 보유한 경우 3점이다. 즉, 특허나 상표에 의한 방어가능성이 높을수록 점수가 높다.

\section{(4) 시장 세분화에 따른 위험 분산}

세분시장, 응용분야 수를 참고하여 계획 사업이 초기에 예 측한 성과를 가져오지 못할 때 이 사업을 다른 세분시장에 적 용할 수 있는가를 평가한다. 여기서 가능한 한 전체시장을 정 교하게 세분화하는 것이 바람직하며, 5년 내 참여할 수 없는 세분시장은 평가 대상에서 제외한다. 그리고 신규 사업을 수행 하는 벤처기업의 경우 가용자원이 부족하므로 초기단계에서는 하나의 세분시장에 집중해야 한다.

Table 6: Risk distribution \& score

\begin{tabular}{|c|c|c|c|}
\hline Market Segment & more than $\mathbf{5}$ & $\mathbf{3}$ types & $\mathbf{1}$ type \\
\hline Score & 10 & 6 & 0 \\
\hline
\end{tabular}

\section{(5) 업계의 재구축}

혁신적 기술로 업계 재구축의 달성 가능성이 매우 높거나, 강력한 선발기업이 구축한 시장구조를 타파할 가능성이 높은 경우 10 점을 부여한다. 그리고 시장구조가 아닌, 제품 또는 판 매형태에 혁신을 초래할 가능성이 있는 경우는 5 점을 부여하 고, 상품의 단순개량인 경우 2점을 부여한다.

\section{(6) 사회적 우위성}

법, 운리, 정치, 사회 그리고 공정거래 법 등의 규제나 제약 들을 평가한다. 정치, 사회, 환경, 공정거래 상 우대사항이 있 으면 10점, 특별한 우대사항 및 마찰사항이 없으면 5점, 수출 입 마찰, 환경오염, 인력부족 등 사회적 마찰이 있는 경우는 2 점을 부여한다.

\subsubsection{2. 자사적합도}

자사 적합도 평가는 평가의 제2단계로서 해당 사업수행 기업 이 검증된 산업 내에서 훌륭하게 사업을 영위해 나갈 수 있을 지의 여부를 평가하는 항목이다. 여기서는 자본력, 마케팅력, 제 조력, 원자재 조달력, 경영지원 등의 요소들을 통해 평가한다.

\section{(1) 자금력(투자규모 및 자금조달)}

사업기회의 잠재성을 실현하기에 충분한 자본(또는 적정 수준 의 부채)이 조달될 수 있는가 평가한다. 자본 집약적 사업일수록 이 척도의 중요성이 증가한다. 평가배점은 아래 <Table $7>$ 과 같다.

Table 7: Required funding capability \& score

\begin{tabular}{|c|c|}
\hline Sufficient response to needed funds & 10 \\
\hline General response to needed funds & 5 \\
\hline Unable to respond to necessary funds & 0 \\
\hline
\end{tabular}

(However, from 0 to 10 points, depending on the degree of responsiveness.) 
(2) 마케팅력(현재의 마케팅력과의 적합성)

창업기업은 한정된 가용자원을 활용하여 효율적으로 마케팅, 영업을 하여 시장을 개척해야 한다. 이를 위해 해당 항목에서 는 고객 서비스, 기술 지원 서비스, 사내 고객 훈련 등의 다양 한 마케팅 역량을 평가한다. 배점 기준은 판로와 판매망을 만 드는 노하우를 얼마나 보유하고 있는가의 여부에 따라 0점에서 10점까지 부여되어 있다. 기존의 마케팅력으로 시장개척이 가 능하면 10점을 부여하고, 새로운 판매망을 개척하고 경영팀도 새로 확보하여 교육시켜야 하면 0점을 부여한다. 특히 유통업 자 브랜드 이미지의 영향요인과 신뢰 및 고객 애호도와의 관계 에 대해 연구한 $\operatorname{Kim}(2015)$ 의 연구를 참고하면, 최근에는 제조 업자 브랜드 제품과 달리 유통업자 브랜드가 광고나 마케팅 비 용이 적어 마케팅운영 효율성을 높일 수 있다는 연구결과들이 나오는 바, 해당 항목을 평가 시 유통업자 브랜드이미지 제고 를 위한 소비자 신뢰도 제고방안에 대한 검토 역시 필요하다.

\section{(3) 제조력(현재의 시설/인력/노하우와의 적합성)}

시장현황에 맞춰 효율적 생산이 가능한 설비를 갖추었는가 를 평가한다. 생산설비의 유연화 정도, 외주생산의 경우 공급업 체의 변동성 정도, 제품 디자인 및 설계 역량 등을 평가한다. 배점기준은 기존의 제조력을 그대로 사용 가능하면 10점(특히 제품수명주기가 짧을 경우)이며, 전혀 없는 경우에는 0점이다. 하지만 서비스 업종의 경우 해당 기준을 적용하기에 어려움이 있어 경영 노하우, 인재 적합성 등을 기준으로 평가한다.

\section{(4) 기술력(현재의 기술/서비스 기획력과의 적합성)}

기업은 고객 기술을 통해 고객 특유의 문제를 해결하고, 기 술 노하우를 적용한 제품/서비스를 기타 세분 시장에도 적용할 수 있어야 한다. 기술사업화에 있어 기술력의 중요성에 대한 반증으로, 최근 아시아지역을 대상으로 한 기술사업화 영향요 인으로 기술의 중요성에 대해 연구한 결과로, Mukhtarova and Zhidebekkyzy(2015)는 카자흐스탄에서 그린경제 영역에서 사 업화지속성을 위해 녹색기술의 중요성을 밝혔고, Saifullah, Kari, and $\mathrm{Ali}(2017)$ 은 말레이시아에서 공공정책과, 녹색기술과 환경관련 제품 간의 관련성을 밝힘으로써 역시 사업화에 있어 기술의 중요성에 대해 언급하였다. 해당 항목에서는 현재 기술 력을 바탕으로 차세대 신기술을 지속적으로 개발하여 기존 시 장을 대체하고 경쟁업체의 시장 진입을 저지할 수 있는가를 평가한다. 또한 신제품을 개발하고, 고객 니즈에 따라 제품을 다양화하고 개선할 수 있는 능력과 새로운 기획과 서비스를 제공할 수 있는 기획력 및 지속력 등을 평가한다.

Table 8: Technical evaluation \& score

\begin{tabular}{|c|c|}
\hline Secured the technology, after sales good after srevice & 10 \\
\hline Secured the technology, after sales bad after sales & 5 \\
\hline No technology, but good after-sales system & 5 \\
\hline No technology, but bad after-sales system & 0 \\
\hline
\end{tabular}

(However, from 0 to 10 points, depending on the degree.)

(5) 원재료 조달력(공급채널 협상력/정보 입수력)

핵심부품 및 원자재 공급중단 등의 변수에 얼마나 효과적으 로 대처할 수 있는가를 평가한다. 즉, 공급 불안정에 대한 사
업 운영상의 민감도를 평가하여 이 민감도가 높을수록 평가는 낮게 내려진다. 필요한 양질의 원자재/부품을 싼 가격에 충분 히 확보할 수 있는가를 평가하고, 서비스업의 경우 고객정보, 신용정보를 확보할 수 있는가를 평가한다. 배점은 조달력에 따 라 0점에서 10점까지 부여한다.

(6) 경영지원(사업에 대한 경영자의 충분한 지원)

경영자의 충분한 지원 즉, 회사 비전과 사업영역에 부합하 며, 경영자가 필요한 자원/인력 등을 지원하고, 최고경영층이 사업에 대한 자신감을 보유한 경우 5점을 부여하고, 강력한 사업추진자가 있으면 5 점을 부여하여 합산한다. 이때 강력한 사업추진자라도 겸업을 하면 4점 이하다.

\subsection{3. $\mathrm{BMO}$ 모델 관련 연구}

국내에서 $\mathrm{BMO}$ 모델 연구는 그동안 주로 비즈니스모델과 관 련하여 이루어졌다. Jeong and Yang(2007)은 벤처기업의 성 공요인과 비즈니스 모델의 구성요소, $\mathrm{BMO}$ 모델 구성요소 간의 상관관계를 분석하여 $\mathrm{BMO}$ 평가모델이 창업기업의 비즈니스 모델 타당성 검토 방법론으로 얼마나 유효한지 검토하였다.

그리고 위의 $\mathrm{BMO}$ 모델 연구를 근거로, 비즈니스모델 평가 프레임워크와 관련된 연구가 이루어졌다. 먼저 Eun(2007)은 $\mathrm{BMO}$ 모델의 자사 적합성 평가항목을 변형하여 인터넷 쇼핑몰 비즈니스 모델 자가평가 방법론을 개발하였는데, 기존 자사적 합성 평가항목이었던 자금력, 마케팅력, 제조력, 기술력, 원재 료 조달력, 경영지원 등의 항목을 경영자특성, 컨텐츠 제공력, 상호작용성 구현 및 운영, 거래안정성 및 상품접근성, 물류, 마케팅력 항목으로 변형하였다.

또한 Lee(2008)은 창업기업의 성장통 극복방안을 위해 비즈 니스모델이 필요함을 언급하고, $\mathrm{BMO}$ 모델을 활용한 비즈니스 모델 분석 프레임워크를 개발하였다. 그는 기존 $\mathrm{BMO}$ 모델의 자사 적합성 평가항목이었던 자금력, 마케팅력, 제조력, 기술 력, 원재료 조달력, 경영지원 등의 항목에서 자금력, 마케팅력, 기술력 항목은 유지하고, 제조력, 원재료 조달력, 경영지원항 목을 경영자 특성, 가용인력 규모, 기업문화 적합성으로 변형 하였다. 하지만 Eun(2007)의 연구와 함께 Lee(2008)의 연구에 서 공통적으로 자사적합성 평가점수 산정시 주관적 판단의 소 지가 있다는 점이 한계점으로 제시되었다.

\section{3. 연구방법론}

이 연구는 창업기업의 성공적인 기술사업화를 위한 효율적 인 방법론을 제안하는 데 있다. 이를 위해 본 연구에서는 선행 연구문헌을 통해 창업기업의 성공요인과 기술사업화 영향요인 간의 상관관계를 이론적으로 검토하였다. 그리고 이러한 상관 관계를 통해, 창업기업에 적용할 수 있는 기술사업화 성공요인 을 제시하였고 이를 $\mathrm{BMO}$ 구성요소 간의 상관관계를 통해, 창 업기업의 기술사업화에 필요한 $\mathrm{BMO}$ 구성요소를 기존 Merrifield $\mathrm{BMO}$ 구성요소에서 변형하였다. 그리하여 구성요소별 가중치를 부여하여 창업기업의 기술사업화에 적합한 모델로 수정하였다. 


\section{4. 연구결과: 창업기업의 기술사업화를 위한 $\mathrm{BMO}$ 모델}

\section{1. 기술사업화에서 $\mathrm{BMO}$ 모델 적용 타당성}

기존의 연구에서 기술사업화를 위해 중요한 요인으로 제시 된 항목들은 경영자의 의지, 사업화자금 조달능력, 연구개발능 력, 경영관리능력, 기술활용능력, 기술이전기관, 시장적 요인, 기술정보능력, 기술선택능력, 기술적용능력, 기술개선능력, 상 품성제고능력, 생산기술능력, 시장조사능력, 시장조건, 상품의 특성, 마케팅능력, 자금능력, 기업의 규모, 기업의 경험, 기업의 자금능력, 기업의 기술능력, 기업의 관리능력 등을 언급했다.

하지만 가용자원이 부족한 초기 창업기업은 위에서 언급한 요인을 모두 확보하는 건 불가능에 가깝다. 따라서 한정된 가용 자원을 효율적으로 활용하여 기술상용과 가능성 및 신규아이템 기획여부 등 사업과 관련된 의사결정을 신속하게 해야 한다.

초기 창업기업 기술사업화는 가용자원의 부족을 극복하며 생존하는 과정이라 해도 과언이 아니다. 따라서 인력과 인프라 등을 포함하여 경영역량, 조직화, 자금, 영업력, 기술력, 생산 능력 등에서 애로사항을 가질 수밖에 없는 제약조건에서 창업 기업은 효율적인 의사결정을 할 수 있는 수단이 필요하다.

따라서 창업기업의 기술사업화 성공가능성 검토를 위해 살펴 보고 있는 $\mathrm{BMO}$ (Bruce Merrifield-Ohe) 모델은 1978년 Merrifield 에 의해 R\&D 프로젝트의 선정방법으로서 제약분석법이라는 이 름으로 개발된 후 일본의 大江연구소에서 수정, 보완하여 $\mathrm{BMO}$ Test로 알려지게 되었는데, 실제로 미국의 벤처기업인들을 대상 으로 한 연구에서 통계적으로 $83 \%$ 이상의 예측력을 보여주었다.

이렇게 벤처기업의 사업타당성 검증에 특화된 $\mathrm{BMO}$ 모델을 기술사업화 타당성 분석에도 활용할 수 있는지 검토하기 위해 먼저 기술사업화 성공요인과 창업기업 성공요인 간의 관련성 을 살펴보았다. 그리하여 Lee and Jang(2001)에서 연구된 $<$ Table 9>, <Table 10>의 내용을 참고하여, <Table 1>에서 검토한 기술사업화 영향요인과 벤처기업 성공요인의 요소상관 정도를 분석하여, 기술사업화 성공요인과 창업기업 성공요인 간에 어떠한 연관성이 있는지 살펴보았다.

Table 9: A Study on the Analysis of Success Factors of Venture Firms

\begin{tabular}{|c|l|l|}
\hline Researcher & \multicolumn{1}{|c|}{ Success factor } & Research method \\
\hline $\begin{array}{c}\text { Roure \& } \\
\text { Maidique } \\
(1986)\end{array}$ & $\begin{array}{l}\text { Experience of collaboration, } \\
\text { perfection of start-up, experience } \\
\text { in related field }\end{array}$ & $\begin{array}{l}\text { Data collection } \\
\text { from companies }\end{array}$ \\
\hline $\begin{array}{c}\text { Hofer \& } \\
\text { Sandberg } \\
(1987)\end{array}$ & $\begin{array}{l}\text { experience, differentiation } \\
\text { strategy, commercial evolution } \\
\text { phase, barrier to entry }\end{array}$ & $\begin{array}{l}\text { An Empirical } \\
\text { Study of 17 } \\
\text { Venture Firms }\end{array}$ \\
\hline & $\begin{array}{l}\text { Capturing attractive market } \\
\text { opportunities, securing initial }\end{array}$ & \\
funding, recruiting core & An empirical \\
souce \& & study against 36 \\
Keeley & personnel, improving technology \\
(1990) & for new products, networking, \\
& additional funding, and strategy \\
formulation & companies \\
\hline $\begin{array}{c}\text { Duchesneau } \\
\text { \& Gartner }\end{array}$ & $\begin{array}{l}\text { Entrepreneurial Characteristics, } \\
\text { Entrepreneurial Behavior, }\end{array}$ & $\begin{array}{l}\text { A survey of 26 } \\
\text { venture } \\
\text { companies }\end{array}$ \\
\hline
\end{tabular}

\begin{tabular}{|c|l|l|}
\hline $\begin{array}{c}\text { Chandler \& Jansen } \\
\text { \& }\end{array}$ & $\begin{array}{l}\text { Entrepreneurial market } \\
\text { opportunity, cognitive ability, } \\
\text { business propulsion ability, } \\
\text { entrepreneurial competence, } \\
\text { entrepreneurial expertise }\end{array}$ & $\begin{array}{l}\text { An Empirical } \\
\text { Study of 134 } \\
\text { Venture Firms }\end{array}$ \\
\hline $\begin{array}{c}\text { Cooper et } \\
\text { al. (1994) }\end{array}$ & $\begin{array}{l}\text { Human capital, management } \\
\text { know-how, industry specific } \\
\text { know-how }\end{array}$ & $\begin{array}{l}\text { An Empirical } \\
\text { Study of 1053 } \\
\text { Entrepreneurs }\end{array}$ \\
\hline
\end{tabular}

Table 10: Difference between a successful venture and a failed venture

\begin{tabular}{|c|c|c|}
\hline & Success factor & Failure Factors \\
\hline $\begin{array}{c}\text { Founder } \\
\text { characteristics }\end{array}$ & $\begin{array}{l}\text { Outstanding management } \\
\text { ability } \\
\text { The breadth of } \\
\text { management experience } \\
\text { Gain a strong start-up team } \\
\text { A high entrepreneurial spirit }\end{array}$ & $\begin{array}{l}\text { Lack of management } \\
\text { skills } \\
\text { Lack of management } \\
\text { resources } \\
\text { A narrow experience } \\
\text { Low Entrepreneurship }\end{array}$ \\
\hline $\begin{array}{c}\text { Founding } \\
\text { process }\end{array}$ & $\begin{array}{l}\text { Awareness of Technology } \\
\text { and Market } \\
\text { Systematic Market } \\
\text { Research and Efforts } \\
\text { Long-term and clear } \\
\text { business plans and models } \\
\text { Take advantage of advice } \\
\text { from external experts }\end{array}$ & $\begin{array}{l}\text { Unclear definition of } \\
\text { business } \\
\text { Short-term outlook and } \\
\text { business plan } \\
\text { Low external expert } \\
\text { utilization } \\
\text { Lack of understanding } \\
\text { about the market }\end{array}$ \\
\hline $\begin{array}{c}\text { Operation } \\
\text { management }\end{array}$ & $\begin{array}{l}\text { Unique management } \\
\text { philosophy and culture } \\
\text { High communication level } \\
\text { Participatory decision } \\
\text { making } \\
\text { A fair compensation system }\end{array}$ & $\begin{array}{l}\text { Human relationship } \\
\text { failure } \\
\text { Inter-departmental } \\
\text { warfare } \\
\text { Non-participatory } \\
\text { decision-making system } \\
\text { Conflicts with external } \\
\text { recruiters }\end{array}$ \\
\hline Strategy & $\begin{array}{l}\text { Low cost strategy } \\
\text { Differentiation Strategy } \\
\text { Strategic flexibility }\end{array}$ & $\begin{array}{l}\text { Non-cooperation of } \\
\text { salesperson } \\
\text { Sales-oriented growth } \\
\text { strategy } \\
\text { Unpretentious } \\
\text { internationalization } \\
\text { strategy }\end{array}$ \\
\hline Resource & $\begin{array}{l}\text { Various funders } \\
\text { Additional funding for } \\
\text { manufacturing and } \\
\text { operations } \\
\text { Outstanding technology } \\
\text { Gain skilled workforce }\end{array}$ & $\begin{array}{l}\text { Fragile distribution } \\
\text { structure } \\
\text { Low technology } \\
\text { Low funding power } \\
\text { Inappropriate } \\
\text { relationship with } \\
\text { investors }\end{array}$ \\
\hline $\begin{array}{l}\text { Industrial } \\
\text { environment }\end{array}$ & $\begin{array}{l}\text { Growth industry } \\
\text { An unbalanced market } \\
\text { Niche market } \\
\text { Easy to identify key } \\
\text { customers and suppliers }\end{array}$ & $\begin{array}{l}\text { Narrow market structure } \\
\text { Industry Maturity } \\
\text { Competition with large } \\
\text { corporations or foreign } \\
\text { joint ventures } \\
\text { Over reliance on } \\
\text { specific customers }\end{array}$ \\
\hline $\begin{array}{c}\text { Company } \\
\text { characteristics }\end{array}$ & $\begin{array}{l}\text { Overcome Generation with } \\
\text { Experience and Knowledge } \\
\text { Overcome the disadvantage } \\
\text { of scale through strategy }\end{array}$ & $\begin{array}{l}\text { Disadvantage of new } \\
\text { generation } \\
\text { Disadvantage of scale }\end{array}$ \\
\hline
\end{tabular}

Jang(2003) 
그리하여 <Table $11>$ 의 세로축에 제시된 창업기업 성공요 인 다섯 가지 즉, 창업자 역량/욕구, 경영전략(저원가/차별화), 외부환경 이해 및 기회포착, 자원(자금, 기술력, 네트워킹), 재 무관리능력은 Lee and Jang(2011) 연구에서 언급된 <Table 9>, <Table 10>을 참고하여 구성하였다. 또한 다음 <Table $11>$ 의 가로축 기술사업화 영향요인은 <Table 1>의 관련변수
를 대입하였다.

<Table 11>에 의하면 기술사업화 영향요인과 창업기업의 성공요인 간에는 밀접한 상관관계가 존재함을 알 수 있다. 이 를 통해 창업기업의 기술사업화 영향요인을 아래 <Table 12> 와 같이 도출하였다.

Table 11: Correlations between Influence Factors of Technology Commercialization and Successful Factors of Entrepreneurs

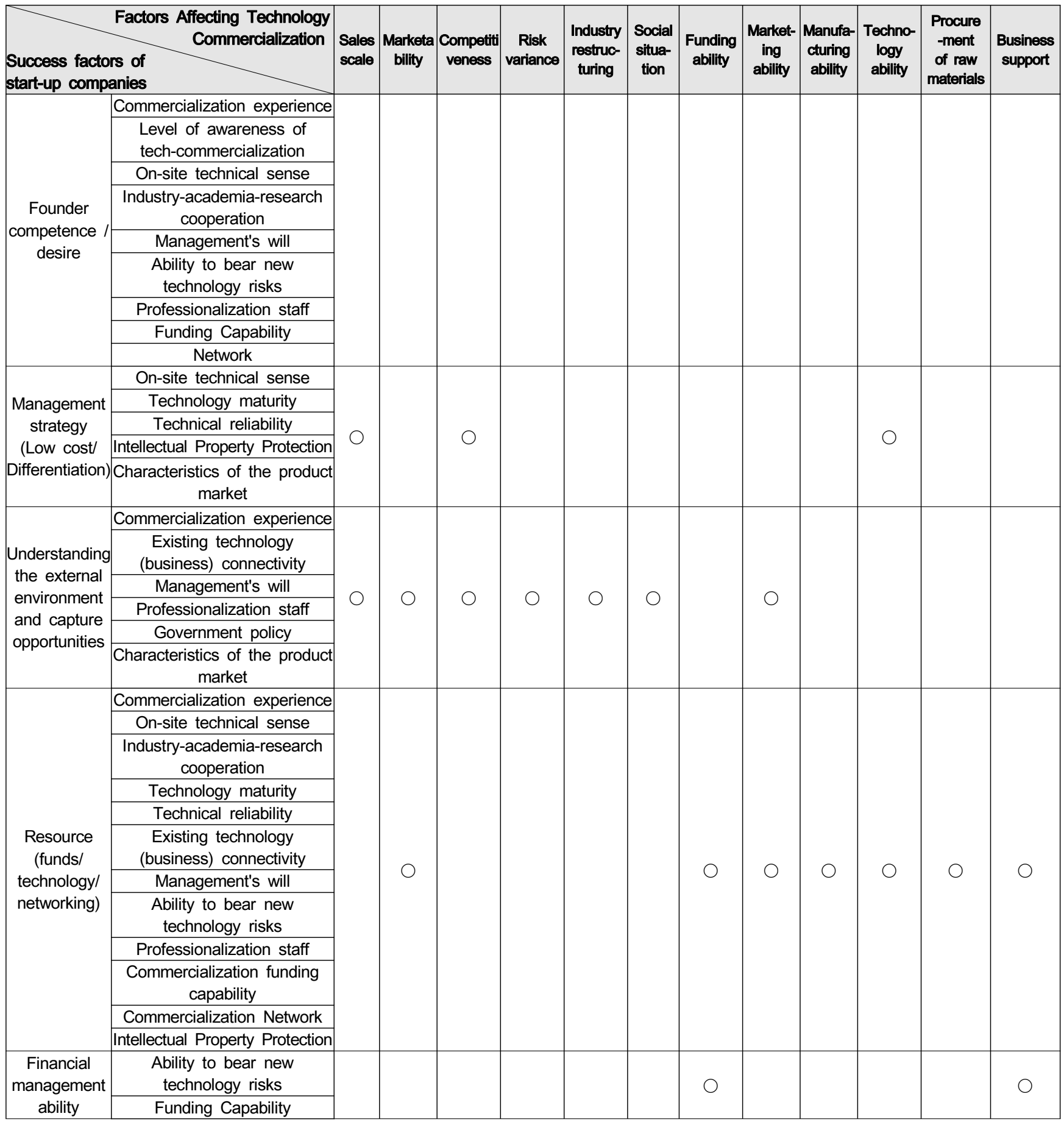


Table 12: Factors Influencing Technology Commercialization of Entrepreneurs

\begin{tabular}{|c|c|c|c|}
\hline $\begin{array}{l}\text { Success factors of } \\
\text { start-up companies }\end{array}$ & $\begin{array}{l}\text { Factors Affecting Technology } \\
\text { Commercialization }\end{array}$ & Count & (\%) \\
\hline $\begin{array}{c}\text { Founder } \\
\text { competence / } \\
\text { desire }\end{array}$ & $\begin{array}{l}\text { Commercialization experience } \\
\text { Level of awareness of } \\
\text { technology commercialization } \\
\text { Management's will } \\
\text { Technology Commercialization } \\
\text { Network }\end{array}$ & 9 & $\begin{array}{r}26.47 \\
(26)\end{array}$ \\
\hline $\begin{array}{l}\text { Management } \\
\text { strategy } \\
\text { (Low cost } \\
\text { /Differentiation) }\end{array}$ & $\begin{array}{l}\text { On-site technical sense } \\
\text { Technology maturity } \\
\text { Technical reliability } \\
\text { Intellectual Property Protection } \\
\text { Characteristics of the product } \\
\text { market }\end{array}$ & 5 & $\begin{array}{c}14.71 \\
(15)\end{array}$ \\
\hline $\begin{array}{l}\text { Understanding the } \\
\text { external } \\
\text { environment and } \\
\text { capture } \\
\text { opportunities }\end{array}$ & $\begin{array}{l}\text { Commercialization experience } \\
\text { Connect with existing } \\
\text { technology (business) } \\
\text { Management's will } \\
\text { Professionalization staff } \\
\text { Government policy } \\
\text { Characteristics of the product } \\
\text { market }\end{array}$ & 6 & $\begin{array}{c}17.65 \\
(18)\end{array}$ \\
\hline $\begin{array}{l}\text { Resource } \\
\text { (funds/ } \\
\text { technology/ } \\
\text { networking) }\end{array}$ & $\begin{array}{l}\text { Commercialization experience } \\
\text { On-site technical sense } \\
\text { Industry-academia-research } \\
\text { cooperation and linkage } \\
\text { Technology maturity } \\
\text { Technical reliability } \\
\text { Link with existing technology } \\
\text { (business) } \\
\text { Management's will } \\
\text { Ability to risk new technology } \\
\text { Professionalization staff } \\
\text { Commercialization funding } \\
\text { capability } \\
\text { Technology Commercialization } \\
\text { Network } \\
\text { Intellectual Property Protection }\end{array}$ & 12 & $\begin{array}{c}35.29 \\
(35)\end{array}$ \\
\hline \multirow[t]{2}{*}{$\begin{array}{c}\text { Financial } \\
\text { management } \\
\text { ability }\end{array}$} & $\begin{array}{l}\text { Ability to risk new technology } \\
\text { Commercialization funding } \\
\text { capability }\end{array}$ & 2 & $\begin{array}{c}5.88 \\
(6)\end{array}$ \\
\hline & & 총29 & $\begin{array}{c}100 \\
(100)\end{array}$ \\
\hline
\end{tabular}

<Table 12>에서는 <Table 11>을 통해 기술사업화 영향요인 과 벤처기업 성공요인의 상관도를 참고하여, 둘 사이의 상관관 계를 정량화하였다. 이는 벤처기업이 기술사업화를 성공적으로 수행하는데 중요한 시사점을 제공한다.

표에 의하면, 첫째 창업성공 요인 중 창업자의 역량 및 욕 구 부분은 기술사업화 영향요인의 사업화 경험, 기술사업화 인 식수준, 현장기술 감각, 산학연 협력 및 연계, 경영자 의지, 신
기술 위험부담 능력, 사업화 전문인력, 사업화 자금도달 능력, 기술사업화 네트워크와 관련이 있음을 나타내고 있다. 그리고 기술사업화 성공에 있어 창업자 특성/역량이 약 $26 \%$ 의 비중이 있음을 확인하였다.

둘째 창업성공 요인 중 경영전략 부분은 기술사업화 영향요 인 중 현장기술감각, 기술성숙도, 기술의 신뢰성, 지식재산권 보호,, 제품시장의 특성과 관련이 있음을 나타내고 있다. 그리 고 기술사업화 성공에 있어 사업전략(차별화전략)이 약 $15 \%$ 의 비중이 있음을 확인하였다.

셋째 창업성공 요인 중 외부환경 이해와 기회포착 부분은 기술사업화 영향요인 중 사업화 경험, 기존기술(사업)과의 연 계성, 경영자의 의지, 사업화 전문인력, 정부정책, 제품시장의 특성과 관련이 있음을 나타낸다. 그리고 기술사업화 성공에 있 어 시장 및 고객이해와 기회포착이 약 $18 \%$ 의 비중이 있음을 확인하였다.

넷째 창업성공 요인 중 자원 즉, 자금, 기술력, 네트워킹 부 분은 기술사업화 성공요인 대부분과 연관되어 있었다. 그리고 기술사업화 성공에 있어 창업자 특성/역량이 약 $35 \%$ 의 비중이 있음을 확인하였다.

다섯째 창업성공 요인 중 재무관리능력은 기술사업화 영향 요인 중 신기술에 대한 위험부담 능력, 사업화 자금조달능력과 관련이 있었다. 그리고 기술사업화 성공에 있어 창업자 특성/ 역량이 약 $6 \%$ 의 비중이 있음을 확인하였다.

따라서 창업기업의 성공요인과 기술사업화 영향요인은 매우 연관성이 높으며, 이를 통해 창업기업에 적합한 기술사업화 영 향요인을 도출할 수 있으며 <Table 12>, 이렇게 도출된 창업 기업의 기술사업화 영향요인을 $\mathrm{BMO}$ 모델 구성요소와 대비하면 $<$ Table 13>과 같다.

표에 의하면 창업기업의 기술사업화 성공요인을 검토할 때 $\mathrm{BMO}$ 평가항목이 유효한 정보를 제공할 수 있음을 나타내고 있다.

첫째 창업기업의 기술사업화 성공요인 중 경영전략이 우수 한지 여부는 $\mathrm{BMO}$ 평가항목 중 매출규모, 경쟁력, 기술력 등 에서 평가가능하다.

둘째 창업기업의 기술사업화 성공요인 중 외부환경의 이해 와 기회포착이 우수한지 여부는 $\mathrm{BMO}$ 평가항목 중 매출규모, 시장성, 경쟁력, 위험분산도, 업계재구축, 사회적 상황, 마케팅 력, 경영지원 등에서 평가가능하다.

셋째 창업기업의 기술사업화 성공요인 중 자원이 우수한지 여부는 $\mathrm{BMO}$ 평가항목 중 시장성, 자금력, 마케팅력, 제조력, 기술력, 원재료조달력, 경영지원 등에서 평가가능하다.

넷째 창업기업의 기술사업화 성공요인 중 재무관리능력이 우수한지 여부는 $\mathrm{BMO}$ 평가항목 중 자금력, 경영지원 등에서 평가가능하다.

따라서 $\mathrm{BMO}$ 평가모형은 창업자특성 부분을 제외하고, 창업 기업의 기술사업화 영향요인의 타당성과 적합성 평가에 상당 히 유효한 모델임을 알 수 있다.

\section{2. 창업기업의 기술사업화 성공을 위한 $\mathrm{BMO}$ 모델}

Merrifield(1987)의 BMO모델의 '사업매력도' 평가항목은 매 출규모, 시장성장성, 경쟁력, 위험분산도, 업계재구축 가능성, 특별한 사회적 상황 등으로 구성되어 있다. 그리고 '자사적합 도' 평가항목은 자금력, 마케팅력, 제조력, 기술력, 원재료조달 력, 경영지원 등으로 구성되어 있다. 
Table 13: Correlation between technology commercialization impact factors and BMO evaluation items

\begin{tabular}{|c|c|c|c|c|c|c|c|c|c|c|c|c|c|}
\hline $\begin{array}{l}\text { Success factors } \\
\text { of start-up } \\
\text { companies }\end{array}$ & $\begin{array}{c}\text { Factors Affecting Technology } \\
\text { Commercialization }\end{array}$ & $\begin{array}{l}\text { Sales } \\
\text { scale }\end{array}$ & $\begin{array}{c}\text { Market- } \\
\text { ability }\end{array}$ & $\begin{array}{l}\text { Competi- } \\
\text { tiveness }\end{array}$ & $\begin{array}{c}\text { Risk } \\
\text { variance }\end{array}$ & $\begin{array}{c}\text { Industry } \\
\text { restructu- } \\
\text { ring }\end{array}$ & $\begin{array}{l}\text { Social } \\
\text { situation }\end{array}$ & $\begin{array}{c}\text { Funding } \\
\text { ability }\end{array}$ & $\begin{array}{l}\text { Market- } \\
\text { ing } \\
\text { ability }\end{array}$ & $\begin{array}{l}\text { Manufac- } \\
\text { turing } \\
\text { ability }\end{array}$ & $\begin{array}{l}\text { Techno- } \\
\text { logy } \\
\text { ability }\end{array}$ & $\begin{array}{c}\text { Procure- } \\
\text { ment } \\
\text { of raw } \\
\text { materials }\end{array}$ & $\begin{array}{c}\text { Business } \\
\text { support }\end{array}$ \\
\hline $\begin{array}{c}\text { Founder } \\
\text { competence / } \\
\text { desire }\end{array}$ & $\begin{array}{l}\text { Commercialization } \\
\text { experience } \\
\text { Level of awareness of } \\
\text { technology commercialization } \\
\text { Management's will } \\
\text { Technology } \\
\text { Commercialization Network }\end{array}$ & & & & & & & & & & & & \\
\hline $\begin{array}{l}\text { Management } \\
\text { strategy } \\
\text { (Low cost } \\
\text { /Differentiation) }\end{array}$ & $\begin{array}{l}\text { On-site technical sense } \\
\text { Technology maturity } \\
\text { Technical reliability } \\
\text { Intellectual Property } \\
\text { Protection } \\
\text { Characteristics of the } \\
\text { product market }\end{array}$ & 0 & & 0 & & & & & & & 0 & & \\
\hline $\begin{array}{l}\text { Understanding } \\
\text { the external } \\
\text { environment } \\
\text { and capture } \\
\text { opportunities }\end{array}$ & $\begin{array}{l}\text { Commercialization experience } \\
\text { Connect with existing } \\
\text { technology (business) } \\
\text { Management's will } \\
\text { Professionalization staff } \\
\text { Government policy } \\
\text { Characteristics of the } \\
\text { product market }\end{array}$ & 0 & 0 & 0 & $\bigcirc$ & 0 & $\bigcirc$ & & $\bigcirc$ & & & & \\
\hline $\begin{array}{l}\text { Resource } \\
\text { (funds/ } \\
\text { technology/ } \\
\text { networking) }\end{array}$ & $\begin{array}{l}\text { Commercialization experience } \\
\text { On-site technical sense } \\
\text { Industry-academia-research } \\
\text { cooperation and linkage } \\
\text { Technology maturity } \\
\text { Technical reliability } \\
\text { Link with existing technology } \\
\text { (business) } \\
\text { Management's will } \\
\text { Ability to risk new technology } \\
\text { Professionalization staff } \\
\text { Commercialization funding } \\
\text { capability } \\
\text { Technology } \\
\text { Commercialization Network } \\
\text { Intellectual Property Protection }\end{array}$ & & 0 & & & & & 0 & $\bigcirc$ & 0 & 0 & $\bigcirc$ & $\bigcirc$ \\
\hline $\begin{array}{c}\text { Financial } \\
\text { management } \\
\text { ability }\end{array}$ & $\begin{array}{l}\text { Ability to risk new technology } \\
\text { Commercialization funding } \\
\text { capability }\end{array}$ & & & & & & & $\bigcirc$ & & & & & $\bigcirc$ \\
\hline
\end{tabular}

창업기업이 기술사업화의 타당성을 평가 시 $\mathrm{BMO}$ 모델이 적 합하다는 근거로 제시한 <Table 13>을 보면, BMO평가항목 12 가지와 창업기업의 기술사업화 영향요인 간에는 매우 밀접 한 상관관계가 있음을 알 수 있었다. 하지만, 창업기업의 기술 사업화 성공요인 중 $26 \%$ 의 비중을 차지하는 창업자역량/욕구 항목에 대응하는 $\mathrm{BMO}$ 모형 구성요소가 없다는 문제가 있었다.

따라서 본 연구에서는 창업기업의 기술사업화 타당성을 검 토하기 위해, 기존의 $\mathrm{BMO}$ 구성요소에 창업자 특성/역량 항목 을 추가하였고, 창업기업의 특성상 제조력과 원재료 조달력 항 목은 비중을 줄여 '외주활용력'으로 구성요소를 변경하여 수정 된 $\mathrm{BMO}$ 모형을 제시하였다. 그리고 기존의 $\mathrm{BMO}$ 모델 관련 연 구에서 한계점으로 제시되었던, $\mathrm{BMO}$ 구성요소별 가중치를 제
시하였다.

창업기업의 기술사업화에 적합하도록 $\mathrm{BMO}$ 구성요소를 추 가-변경하면서 제시된 가중치 적용방식은 기존 $\mathrm{BMO}$ 모델의 120 점 만점의 단순 합산이 아닌, 구성요소별로 가중치를 적용 한 총점 10 점 만점의 가중점수 합산방식으로 변경함으로써 해 결하였다.

변경된 $\mathrm{BMO}$ 모델의 구성요소별 가중치는, <Table 12>에서 영향요인 비중을 정할 때 기준으로 삼았던 기술사업화 영향요 인 개수를 근거로, 변형 $\mathrm{BMO}$ 구성요소에 해당하는 창업기업 기술사업화 영향요인 1 개 당 1점에 해당되는 개수별 합산점수 를 부여하여 가중치를 정하였다. 이상의 내용을 정리하면 아래 $<$ Table $14>$ 와 같다. 
그리고 <Table 14>를 근거로 창업기업의 기술사업화 타당 성 검토를 위해, 변형Merrifield의 $\mathrm{BMO}$ 모델 평가항목에는 가중 치가 차등 부여되지 않았기에 각각의 구성요소를 동일한 비중 과 같은 배점으로 합산하여 평가하며, 사업매력도와 자사적합 도를 합한 총점이 120점이며, 사업매력도 60점 만점에 35점 이상이 되면, 2단계 자사적합도 평가로 진행되며, 사업매력도 와 자사적합도 평가의 합이 80점 이상이면 사업진입이 매력이 있는 것으로 평가하였다.

하지만 창업기업의 기술사업화 타당성 검토를 위한, 변형된 사업매력도에는 가중치가 부여되었기 때문에 기존 $\mathrm{BMO}$ 모델과 같이 점수의 단순합산방식으로 사업매력도를 평가할 수 없다. 따라서 위 그림에서는 '비교의 편의상' 기존 사업매력도의 평 가항목에 동일한 가중치 $8.33 \%$ 를 부여하였는데 이는 $\mathrm{BMO}$ 모 델의 12 가지 구성요소의 배점항목이 10 점씩 동일한 것에 근거
하여, 가중치 총합 $100 \%$ 을 12 로 나눈 수치다. 이 가중치를 $\mathrm{BMO}$ 모델의 평가항목 배점에 적용하면, 최종 점수가 도출된다. Merrifield의 $\mathrm{BMO}$ 모델과 창업기업의 기술사업화를 위한 $\mathrm{BMO}$ 모델의 구성요소별 가중치와 가중점수를 비교하면 다음 $<$ Table 15>와 같다.

그리고 기존의 $\mathrm{BMO}$ 모델의 사업매력도 평가에서 60점 만점 에 기준점수인 35점 이상 되면, 2단계 자사적합도 평가로 진 행되지만 변형된 $\mathrm{BMO}$ 모델의 사업매력도 평가에서는, 가중치 를 부여한 자사적합도의 평가항목만 평가하되, 기존 $\mathrm{BMO}$ 모 델의 1 단계 기준점수 35 점이 총 원점수(120점)의 $29.17 \%$ 에 해당된다는 점에 근거하여, 가중치를 적용한 총 가중점수 총점 (10점)의 $29.17 \%$ 인 2.92점 이상이 되면 2단계 자사적합도 평 가로 넘어간다.

Table 14: Weight by BMO component

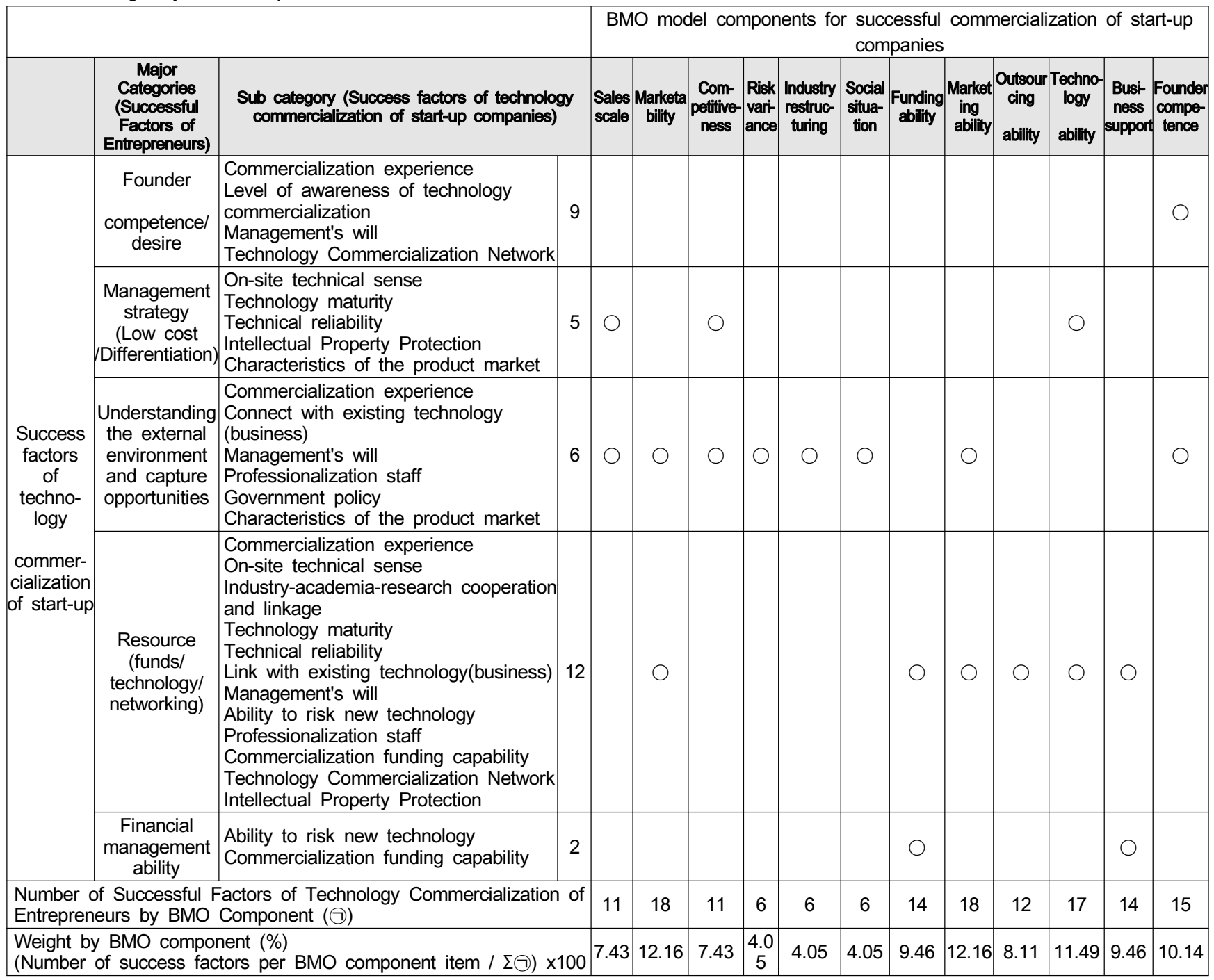


Table 15: Component evaluation of BMO model for technical commercialization of start-up companies

\begin{tabular}{|c|c|c|c|c|c|c|c|c|}
\hline & \multicolumn{4}{|c|}{ Merrifield's BMO model } & \multicolumn{4}{|c|}{$\begin{array}{l}\text { BMO model for technology commercialization of start-up } \\
\text { companies }\end{array}$} \\
\hline \multirow{7}{*}{$\begin{array}{c}\text { Business } \\
\text { attractiveness }\end{array}$} & Evaluation items & $\begin{array}{l}\text { original } \\
\text { score }\end{array}$ & $\begin{array}{c}\text { weight } \\
(\%)\end{array}$ & $\begin{array}{l}\text { weighted } \\
\text { score }\end{array}$ & Evaluation items & $\begin{array}{c}\text { original } \\
\text { score }\end{array}$ & $\begin{array}{l}\text { weight } \\
(\%)\end{array}$ & $\begin{array}{c}\text { weighted } \\
\text { score }\end{array}$ \\
\hline & $\begin{array}{c}\text { Market size } \\
\text { (scale } 5 \text { points, } \\
\text { profit ratio } 5 \text { points) }\end{array}$ & 10 & 8.33 & 0.83 & $\begin{array}{c}\text { Market size } \\
\text { (scale } 5 \text { points, } \\
\text { profit ratio } 5 \text { points) }\end{array}$ & 10 & 7.43 & 0.74 \\
\hline & $\begin{array}{l}\text { Market Growth } \\
\text { (Growth rate } 5 \text { points, } \\
\text { market share } 5 \text { points) }\end{array}$ & 10 & 8.33 & 0.83 & $\begin{array}{l}\text { Market Growth } \\
\text { (Growth rate } 5 \text { points, } \\
\text { market share } 5 \text { points) }\end{array}$ & 10 & 12.16 & 1.22 \\
\hline & $\begin{array}{l}\text { Competitiveness } \\
\text { (corresponding strength 4point } \\
\text { /life 3point /intellectual property } \\
\text { rights 3point) }\end{array}$ & 10 & 8.33 & 0.83 & $\begin{array}{c}\text { Competitiveness } \\
\text { (corresponding strength 4point } \\
\text { /life 3point /intellectual property } \\
\text { rights 3point) }\end{array}$ & 10 & 7.43 & 0.74 \\
\hline & $\begin{array}{c}\text { Risk variance } \\
\text { (Number of application fields) }\end{array}$ & 10 & 8.33 & 0.83 & $\begin{array}{c}\text { Risk variance } \\
\text { (Number of application fields) }\end{array}$ & 10 & 4.05 & 0.41 \\
\hline & Industry Rebuildability & 10 & 8.33 & 0.83 & Industry Rebuildability & 10 & 4.05 & 0.41 \\
\hline & A special social situation & 10 & 8.33 & 0.83 & A special social situation & 10 & 4.05 & 0.41 \\
\hline \multirow{6}{*}{ Business } & Funding ability & 10 & 8.33 & 0.83 & Funding ability & 10 & 9.46 & 0.95 \\
\hline & Marketing ability & 10 & 8.33 & 0.83 & Marketing ability & 10 & 12.16 & 1.22 \\
\hline & Manufacturing ability & 10 & 8.33 & 0.83 & Outsoucing ability & 10 & 8.11 & 0.81 \\
\hline & Technology ability & 10 & 8.33 & 0.83 & Technology ability & 10 & 11.49 & 1.15 \\
\hline & Procurement of raw materials & 10 & 8.33 & 0.83 & Business Support & 10 & 9.46 & 0.95 \\
\hline & Business Support & 10 & 8.33 & 0.83 & Founder competence / desire & 10 & 10.14 & 1.01 \\
\hline
\end{tabular}

Table 16: BMO model for technology commercialization of start-up companies

\begin{tabular}{|c|c|c|c|c|c|c|}
\hline & \multicolumn{2}{|l|}{ Merrifield's BMO model } & \multicolumn{4}{|c|}{ BMO model for technology commercialization of start-up companies } \\
\hline \multirow{7}{*}{$\begin{array}{c}\text { Busine } \\
\text { ss } \\
\\
\text { attracti } \\
\text { veness }\end{array}$} & Evaluation items & $\begin{array}{c}\text { original } \\
\text { score }\end{array}$ & 평가항목 & $\begin{array}{l}\text { original } \\
\text { score }\end{array}$ & $\begin{array}{l}\text { weight } \\
(\%)\end{array}$ & $\begin{array}{l}\text { weighted } \\
\text { score }\end{array}$ \\
\hline & $\begin{array}{c}\text { Market size } \\
\text { (scale } 5 \text { points, profit ratio } 5 \text { points) }\end{array}$ & 10 & $\begin{array}{c}\text { Market size } \\
\text { (scale } 5 \text { points, profit ratio } 5 \text { points) }\end{array}$ & 10 & 7.43 & 0.74 \\
\hline & $\begin{array}{c}\text { Market Growth } \\
\text { (Growth rate } 5 \text { points, } \\
\text { market share } 5 \text { points) }\end{array}$ & 10 & $\begin{array}{l}\text { Market Growth } \\
\text { (Growth rate } 5 \text { points, } \\
\text { market share } 5 \text { points }\end{array}$ & 10 & 12.16 & 1.22 \\
\hline & \begin{tabular}{|c|} 
Competitiveness \\
(corresponding strength 4point \\
/life 3point /intellectual property rights \\
3point)
\end{tabular} & 10 & $\begin{array}{c}\text { Competitiveness } \\
\text { (corresponding strength 4point } \\
\text { /life 3point /intellectual property rights } \\
\text { 3point) }\end{array}$ & 10 & 7.43 & 0.74 \\
\hline & $\begin{array}{c}\text { Risk variance } \\
\text { (Number of application fields) }\end{array}$ & 10 & $\begin{array}{c}\text { Risk variance } \\
\text { (Number of application fields) }\end{array}$ & 10 & 4.05 & 0.41 \\
\hline & Industry Rebuildability & 10 & Industry Rebuildability & 10 & 4.05 & 0.41 \\
\hline & A special social situation & 10 & A special social situation & 10 & 4.05 & 0.41 \\
\hline \multirow{6}{*}{$\begin{array}{c}\text { Busine } \\
\text { ss }\end{array}$} & Funding ability & 10 & Funding ability & 10 & 9.46 & 0.95 \\
\hline & Marketing ability & 10 & Marketing ability & 10 & 12.16 & 1.22 \\
\hline & Manufacturing ability & 10 & Outsoucing ability & 10 & 8.11 & 0.81 \\
\hline & Technology ability & 10 & Technology ability & 10 & 11.49 & 1.15 \\
\hline & Procurement of raw materials & 10 & Business Support & 10 & 9.46 & 0.95 \\
\hline & Business Support & 10 & Founder competence/desire & 10 & 10.14 & 1.01 \\
\hline & total score & 120 & \multicolumn{3}{|l|}{ total weighted score } & 10 \\
\hline
\end{tabular}

변형된 $\mathrm{BMO}$ 모델의 2단계 자사적합도 평가 역시 평가항목 에 따라 가중치를 적용한 최종합산점수로 평가한다. 이때, 기 존 $\mathrm{BMO}$ 모델의 경우 사업매력도와 자사적합도 평가의 총 배점 120점에서 80점이 넘으면 사업진입이 매력적인 것으로 평가하 였다. 하지만 변형된 $\mathrm{BMO}$ 모델의 2단계 평가에서는, 가중치를 부여한 사업매력도와 자사적합도를 평가하되, 기존 $\mathrm{BMO}$ 모델
의 2단계 기준점수인 80 점이 총 원점수(120점)의 $66.67 \%$ 에 해당된다는 점에 근거하여, 가중치를 적용한 총 가중점수(10 점)의 $66.76 \%$ 인 6.67 점 이상이 가중점수의 총합이 되면 창업 기업의 기술사업화 성공가능성이 높은 것으로 평가한다.

지금까지 언급한 내용을 표로 정리하면 다음 <Table 16>, <Table 17>과 같다. 이때 사업매력도 평가 시 추정시장 규모 
배점은 Merrifield의 경우 <Table 3>에서 언급하였던 것처럼, 시장규모가 1조원 이상인 경우 최고 배점 5점을 부여하였으 나, 창업기업의 기술사업화와 관련된 본 연구에서는 시장규모 천억 이상인 경우 최고 배점 5점을 부여하고, 최고 5점에서 최저 1점까지의 배점 등급기준은 <Table 18>과 같이 제시하 며, 투자효율 배점은 기존 모델과 동일하게 부여한다.

그리고 창업자 역량은 <Table 13>에 제시된 창업기업 성공 요인과 $\mathrm{BMO}$ 평가항목 간 상관관계에서 도출한 창업기업의 기 술사업화 영향요인을 기준으로 원점수 배점을 구성하여 $<$ Table 19>에 제시하였다.

또한 <Figure 3>은 Merrifield의 BMO모델에 의한 사업성(매 력도+적합성) 평가점수에 따른 성공확률을 나타낸 곡선과, 본 연구에서 제시된 창업기업의 기술사업화를 위한 $\mathrm{BMO}$ 모델에 의한 기술사업화 성공가능성(매력도+적합성) 점수에 따른 성공 확률을 나타낸 곡선이다. Merrifield의 $\mathrm{BMO}$ 모델의 경우 사업성 평가점수가 80 점 이상인 경우에 사업화를 추진하는 것이 바람 직한 것으로 판단되었고, 창업기업의 기술사업화를 위한 $\mathrm{BMO}$ 모델 에서는, <Table 20>에서 보는 것과 같이 Merrifield의 모 델 사업성 평가점수인 80 점이, 총점 120 점(기준배점) 대비 $66.67 \%$ 인 점에 착안하여, 창업기업의 기술사업화 평가를 위한 $\mathrm{BMO}$ 모델에서는 기준배점 10 점의 $66.67 \%$ 인 6.67 점이 넘을 경 우 기술사업화 성공가능성이 높은 것으로 평가한다.

Table 17: Merrifield's BMO model and the BMO model for technology commercialization of start-ups

\begin{tabular}{|c|c|c|c|}
\hline & $\begin{array}{c}\text { Merrifield's } \\
\text { BMO model }\end{array}$ & $\begin{array}{c}\text { BMO model for } \\
\text { technology } \\
\text { commercialization of } \\
\text { start-up companies }\end{array}$ & 비고 \\
\hline $\begin{array}{c}\text { original } \\
\text { score }\end{array}$ & 10 & 10 & \\
\hline $\begin{array}{c}\text { original } \\
\text { total score }\end{array}$ & $\begin{array}{c}120 \\
\text { (evaluation criteria) }\end{array}$ & Not applicable & \\
\hline $\begin{array}{c}\text { weighted } \\
\text { total score }\end{array}$ & Not applicable & $\begin{array}{c}10 \\
\text { (evaluation criteria) }\end{array}$ & \\
\hline $\begin{array}{c}\text { Step 1 } \\
\text { standard } \\
\text { score }\end{array}$ & 35 & 2.92 & $\begin{array}{c}\text { Compared with } \\
\text { the standard, } \\
29.17 \%\end{array}$ \\
\hline $\begin{array}{c}\text { Step 2 } \\
\text { standard } \\
\text { score }\end{array}$ & 80 & 6.67 & $\begin{array}{c}\text { Compared with } \\
\text { the standard, } \\
66.67 \%\end{array}$ \\
\hline
\end{tabular}

Table 18: Estimation of business attractiveness of BMO model for technology commercialization Estimation of market size

\begin{tabular}{|c|c|c|c|c|c|}
\hline $\begin{array}{c}\text { Market } \\
\text { size }\end{array}$ & $\begin{array}{c}\text { more than } \\
1 \text { trillion } \\
\text { won }\end{array}$ & $\begin{array}{c}\text { less than } \mathbf{1} \\
\text { trillion won }\end{array}$ & $\begin{array}{c}\text { less than } \\
\mathbf{5 0 0} \text { billon } \\
\text { won }\end{array}$ & $\begin{array}{c}\text { less than } \\
\mathbf{5 0 0} \text { billion } \\
\text { won }\end{array}$ & $\begin{array}{c}\text { less than } \\
10 \text { billion } \\
\text { won }\end{array}$ \\
\hline score & 5 & 4 & 3 & 2 & 1 \\
\hline \multicolumn{7}{|c|}{ Estimated market Scaling } \\
$\downarrow$ \\
시장규모 & $\begin{array}{c}\text { more than } \\
100 \text { billion } \\
\text { won }\end{array}$ & $\begin{array}{c}\text { less than } \\
100 \text { billion } \\
\text { won }\end{array}$ & $\begin{array}{c}\text { less than } \\
50 \text { billion } \\
\text { won }\end{array}$ & $\begin{array}{c}\text { less than } \\
10 \text { billion } \\
\text { won }\end{array}$ & $\begin{array}{l}\text { less than } 1 \\
\text { billion won }\end{array}$ \\
\hline score & 5 & 4 & 3 & 2 & 1 \\
\hline
\end{tabular}

Table 19: Founder competency evaluation index and rating

\begin{tabular}{|c|c|c|}
\hline Item & Evaluation index & $\begin{array}{c}\text { Scor } \\
\mathbf{e}\end{array}$ \\
\hline $\begin{array}{c}\text { Founder } \\
\text { competence }\end{array}$ & $\begin{array}{c}\text { Commercialization experience, recognition } \\
\text { level of technical commercialization, } \\
\text { management's will, technical } \\
\text { commercialization network }\end{array}$ & 10 \\
\hline
\end{tabular}

Table 20: Based on the evaluation criteria

\begin{tabular}{|c|c|l|}
\hline $\begin{array}{c}\text { Evaluation } \\
\text { standard }\end{array}$ & score & 비고 \\
\hline Perfect fit & 10 & 세부 평가항목 중 $100 \%$ 충족하는 경우 \\
\hline fit & 7 & 세부 평가항목 중 $70 \%$ 충족하는 경우 \\
\hline usual & 5 & 세부 평가항목 중 $50 \%$ 충족하는 경우 \\
\hline unsuitable & 3 & 세부 평가항목 중 $30 \%$ 충족하는 경우 \\
\hline $\begin{array}{c}\text { Totally } \\
\text { unsuitable }\end{array}$ & 0 & 세부 평가항목 중 0\% 충족하는 경우 \\
\hline
\end{tabular}

한편 <Figure 4>는 BMO 평가결과에 대한 사업화 추진결정 조건을 나타낸 도식으로서, 해당사업의 매력도가 35점 이상인 경우 사업화 추진을 검토하되 사업성(매력도+적합성)이 80점 이상인 경우 사업화 추진을 결정한다.
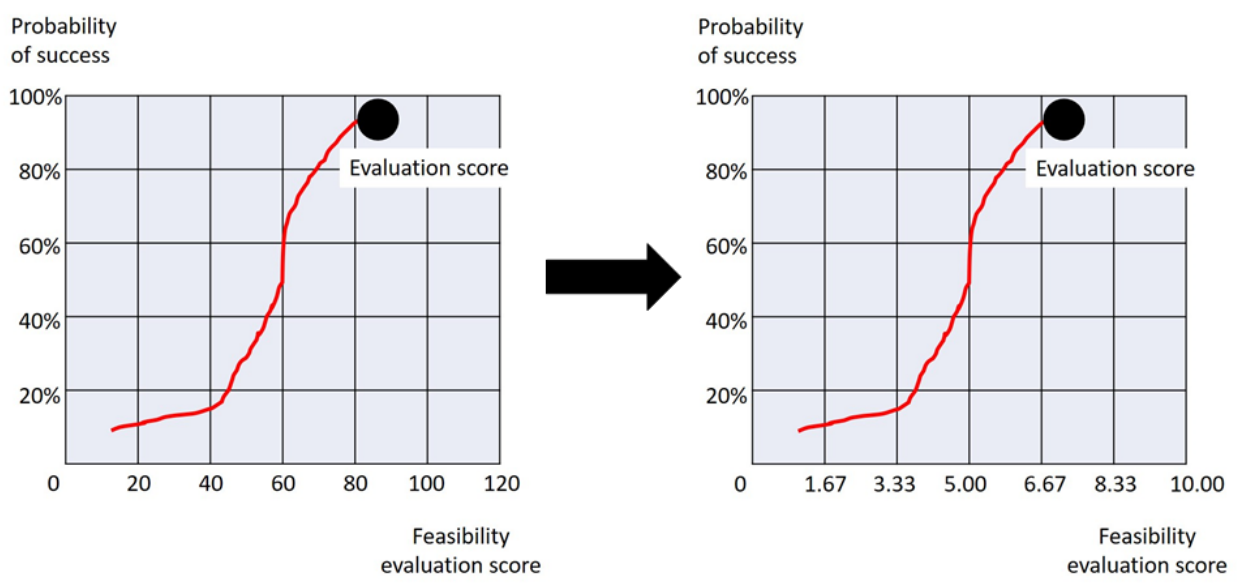

Figure 3: Merrifield's BMO model commercial success probability <left>과

The probability of commercialization of BMO model for technology commercialization of start-up companies <right> 


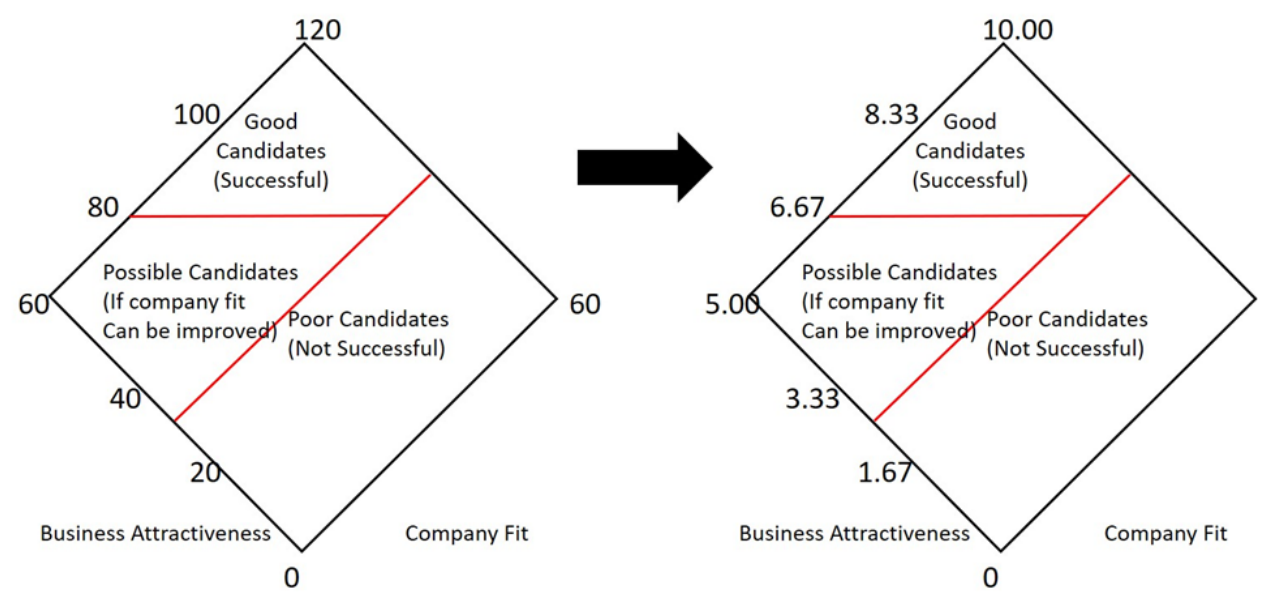

Fgure 4: Merrifield's BMO Model Commercialization Decision Model <left>과

Decision model for BMO model commercialization for technology commercialization of start-up companies <right>

5. 결론

\section{1. 연구결과 요약}

지금까지 본 연구에서는 창업기업이 기술사업화 과정 중에 검토해야 할 요소들을 Merrifield가 제안한 $\mathrm{BMO}$ 방법을 활용하 여 살펴보았다.

이를 위해 다음의 작업을 수행하였다. 먼저, 선행연구를 통 해 기술사업화성공의 정의와 영향요인들을 살펴보았다. 그리고 이 기술사업화 영향요인과 벤처기업의 성공요인의 상관관계를 분석한 결과 둘 사이에 매우 밀접한 관련이 있음을 확인하였 고 이를 통해 ‘창업기업의 기술사업화 성공요인'을 5 가지 범주 로 제시하였다.

이렇게 제시된 '창업기업의 기술사업화 성공요인'과 $\mathrm{BMO}$ 구 성요소의 상관관계를 조사하였고, 그 결과 둘 사이에도 매우 밀접한 관련성이 있음을 확인하였으나, 기존 $\mathrm{BMO}$ 모델의 구성 요소가 창업기업의 기술사업화의 성공요인에 좀 더 높은 상관 관계를 가지려면, 위 기술사업화 성공요인 중 $13.79 \%$ 를 차지 하는 ‘창업자 역량'부분이 보완되어야 할 필요성을 발견했다.

그리하여 본 연구에서는 Merrifield의 BMO모델을 창업기업 의 기술사업화에 적합하게 수정하였고, 수정된 $\mathrm{BMO}$ 모델의 구 성요소별로 가중치를 부여하여 창업기업의 기술사업화를 위한 $\mathrm{BMO}$ 모델을 제시하였다.

다만, Merrifield의 $\mathrm{BMO}$ 모델의 경우는 12 개의 구성요소별 매긴 점수의 합산방식으로 사업성을 평가하였으나, 본 연구에 서 다루는 창업기업의 기술사업화를 위해 변형된 $\mathrm{BMO}$ 모델의 경우 기존 모델의 구성요소에서 창업자역량이 추가된 13 개의 구성요소를 다루는 바, 단순한 점수합산방식이 아닌, 구성요소 별로 비중에 따른 가중치를 부여한 가중점수의 합산방식으로 창업기업의 기술사업화 성공가능성을 평가하였다.

이때 점수 평가 기준은 기존 Merrified의 $\mathrm{BMO}$ 구성요소의 합산점수 평가시, 1 단계 통과기준 점수인 35 점이 총점대비 $29.17 \%$ 의 비중을 차지하며, 2단계 기준점수인 사업성평가점수 80 점이 총점대비 $66.67 \%$ 의 비중을 차지하는 점을 고려하여, 변형된 $\mathrm{BMO}$ 모델의 구성요소별 가중치 합산 방식의 기준점수
역시, 가중치 총합 10 점 대비 $29.17 \%$ 인 2.92점을 1단계 통과 기준 점수로 정하였고, 2 단계 기준점수인 사업성평가점수는 가중치 총합 10 점 대비 $66.67 \%$ 인 6.67 점으로 정하였다.

\section{2. 시사점 및 향후 연구방향}

본 연구의 시사점 및 향후 연구방향은 다음과 같다.

먼저 시사점으로 첫째, 그동안 $\mathrm{BMO}$ 관련 연구에서 한계점으 로 제시되었던, $\mathrm{BMO}$ 모델의 구성요소별 가중치 적용을 시도하 였다. 그리고 이를 위해 점수합산방식이 아닌, 구성요소별 비 중에 따른 가중치를 부여한 가중점수 합산방식을 적용하였다.

둘째, 기존 $\mathrm{BMO}$ 모델 연구는 창업기업의 사업성 평가 혹은 성장통 극복방안을 위해 비즈니스모델의 중요성을 언급하고, 이를 $\mathrm{BMO}$ 모델의 구성요소 변형을 통해 해당 사업아이템의 비 즈니스모델을 평가하는데 중점을 두었다면, 본 연구는 창업기 업의 기술사업화에 적합한 $\mathrm{BMO}$ 모델을 제시하였다는 데 의의 가 있다.

셋째, $\mathrm{BMO}$ 모델에 의한 사업성 평가뿐만 아니라 앞으로 나 아갈 방향에 대한 전략을 제시하였다.

하지만 $\mathrm{BMO}$ 모형이 투자 및 사업타당성평가 실무 등에서 다방면으로 활용되고 있다고는 하나, 해당 모형을 적용한 사례 연구는 회사의 영업비밀 공개제한 등을 이유로 충분히 이루어 지지 않고 있는 현황이다. 따라서 향후 다양한 영역의 사례연 구를 통해 산업별로 특화되어 보완된 모델연구를 기대한다.

\section{References}

Berry, L. G., \& Goel, R. K. (1991). Guidelines for Successfully Transferring Government-Sponsered Innovation. Research Policy, 20(2), 121-143.

Chen, C. -J. (2008). Technology commercialization, incubator and venture capital, and new venture performance. Journal of business research, 62(1), 93-103.

Cooper, R. G. (1979). The Dimensions of Industrial New 
Product Success and Failure. Journal of Marketing, 43(3), 93-103.

Eun, J. S. (2007). A series of rearch for the theory of self-estimating internet shoping-mall, business model which uses BMO estimating model. (Master Thesis, Hanbat Nationnal University). Retrieved October 10, 2018

Ettlie, J. E. (1982). The Commercialization of Federally Sponsored Technological Innovations. Research Policy, 11(3), 173-192.

Fleischauer, P., Goeller, B., Hederman, W., Johnson, L., Morrow, E., Rettig, R., \& Wirt, J. (1979). Analysis of Federally Funded Demonstration Project: Supporting Case Studies. Santa Monica, CA: RAND Corporation.

Gokhan, C., Ferruh, I., \& Adnan, H. (2016). How Managers React to Crisis?: A Planned Behavior Theory. East Asian Journal of Business Management, 6(4), 5-12.

Han, S. S. (2016). Industry Structure, Technology Characteristics, Technology Marketing and Performance of Technology - Based Start-ups: With Focus on Technology Marketing Strategy. Journal of Distribution Science, 14(2), 93-101.

, Jung, H. Y., Yang, Y. S. (2007). Literature Studies for Testing validity of Business Model of High-tech Starts-up;Utilizing BMO Model. Asia-Pacific Journal of Business Venturing and Entrepreneurship, 2(2), 1-22.

Kim, W. K. (2014). A Study on the Factors that Affect the Negotiation of Technology Trading for Promotion of Technology Transfer Commercialization. Journal of Distribution Science, 12(1), 35-46.

Kim, Y. -K. (2015). Relationships between the Effect Factors of Private Brand Images and Customer Trust and Loyalty, Journal of Distribution Science, 13(7), 73-83.

Lee, J. S. (2007). A study on overcoming the growing pains of start-up entrepreneur-A case study on $\mathrm{K}$ company based on BMO model. (Master Thesis, Hanbat Nationnal University). Retrieved October 10, 2018

Lee, J. W., Jang, S. D. (2001). Success Factor of High-Tech Ventures Across Stages of Growth. Journal of Management, 9(2), 59-92.

Lee, S. C., Lim, W. H., \& Suh, E. K. (2014). Youth Startup Firms: A Case Study on the Survival Strategy for Creating Business Performance. Journal of Distribution Science, 12(6), 81-88.

Lester, D. H. (1998). Critical Success Factors for New Product Development. Research Technology Management, 41(1), 36-43.
Lin, B. -W., Lee, W., \& Hung, S. -C. (2006). R\&D intensity and commercialization orientation effects on financial performance. Journal of business research, 596), 679-685.

Merrifield, D. B. (1978, December). How to select successful R\&D projects. Management Review, 25-39.

Mukhatarova, K. S., \& Zhidebekkyzy, A. (2015). Development of Green Economy via Commercialization of Green Technologies: Experience of Kazakhstan. Journal of Asian Finance, Economy and Business, 2(4), 21-29.

Rothwell, R. (1992). Successful Industrial Innovation: Critical Factors for the 1990s. $R \& D$ Management, 22(3), 221-240.

Saifullah, K., Kari, F. B., \& Ali, A. (2017). Linkage between Public Policy, Green Technology and Green Products on Environmental Awareness in the Urban Kuala Lumpur, Malaysia. Journal of Asian Finance Economics and Business, 4(2), 45-53.

Sara, M., \& Yi, Y. (2016). From an Entrepreneur to a Sustainopreneur: Extracting Facts about Sustainopreneurship. East Asian Journal of Business Management, 6(2), 23-25.

Shan, Y., \& Shuai, S. (2014). A Study of the Factors that Impact Chinese Consumers' Purchasing Intent for High-Tech Products. East Asian Journal of Business Management 4(1), 37-40.

Song, D. H. (2006). A study on Promoting Diffusion of Government funded Research \& Development Outcome. KISTEP.

Song, J. B. (2002). A study on commercialization and diffusion of the research results from company-attached research institutions, Journal of Hankyung University, 34th.

Wind, Y. (2005). Marketing as an engine of business growth: A cross-functional perspective. Journal of business research 58(7), 863-973.

Yam, R. C. M., Guam, J. C., Pum, K. F., \& Tang, E. P. Y. (2004). An audit of technological innovation capabilities in chinese firms: some empirical findings in Beijing, China. Research Policy, 33, 1123-1140.

Yuan, N. A., Thanh, N. M., \& Loe, T. T. (2018). Technology Management and Challenges of Vitnamese Enterprises in the International Market. Journal of Asian Finance Economics and Business, 5(1), 43-52.

Zahra, S. A., \& Nielsen, A. P. (2002). Sources of capabilities, integration and technology commercialization. Strategic Management Journal, 23(5), 377-398. 